\title{
Filling the Accountability Gap in Structured Finance Transactions. The Case for a Broader Fiduciary Obligation
}

DOI:

10.2139/ssrn.2529413

\section{Document Version}

Accepted author manuscript

Link to publication record in Manchester Research Explorer

\section{Citation for published version (APA):}

Bavoso, V. (2017). Filling the Accountability Gap in Structured Finance Transactions. The Case for a Broader Fiduciary Obligation. Columbia Journal of European Law, 23(2), 370-400. https://doi.org/10.2139/ssrn.2529413

\section{Published in:}

Columbia Journal of European Law

\section{Citing this paper}

Please note that where the full-text provided on Manchester Research Explorer is the Author Accepted Manuscript or Proof version this may differ from the final Published version. If citing, it is advised that you check and use the publisher's definitive version.

\section{General rights}

Copyright and moral rights for the publications made accessible in the Research Explorer are retained by the authors and/or other copyright owners and it is a condition of accessing publications that users recognise and abide by the legal requirements associated with these rights.

\section{Takedown policy}

If you believe that this document breaches copyright please refer to the University of Manchester's Takedown Procedures [http://man.ac.uk/04Y6Bo] or contact uml.scholarlycommunications@manchester.ac.uk providing relevant details, so we can investigate your claim.

\section{OPEN ACCESS}




\title{
Filling the accountability gap in structured finance transactions: The case for a broader fiduciary obligation
}

\author{
Vincenzo Bavoso ${ }^{1}$
}

\begin{abstract}
This article examines the legal structure of complex structured finance transactions - notably collateralised debt obligation (CDO) - and explores in particular the regime of legal duties and liabilities designed to protect investors. The article critically assesses whether the existing law is adequate to hold to account the main actors involved in these transactions, namely SPV directors, trustees and asset managers. It also explores more specific avenues to establish accountability, namely the law of misrepresentation and fiduciary law. The analysis shows that in the context of structured transactions there remains an accountability problem due to the limited extent of the applicable duties, the nature of the conflicts of interest, the problematic disclosure (misrepresentation) of the transactions' risks. The article contends that the complexity of the legal relationships underpinning CDOs and the resulting asymmetry of information between financial institutions on the one hand and investors on the other pushes for either a broader application of fiduciary obligations or alternatively a statutory redefinition of structured transactions.
\end{abstract}

A - Introduction

B - Legal problems and risks in complex structured transactions: synthetic CDO

1 - The Abacus CDO

$\mathrm{C}$ - Regulating accountability in CDO transactions

1 - Directors

2 - Trustees

3 - Asset managers

D - Bridging the accountability gap

1 - Fiduciary law

2 - The law of misrepresentation

E - Critical reflections and conclusion

\footnotetext{
${ }^{1}$ Lecturer in Commercial Law, University of Manchester and Research Associate in the Tipping Points project, Institute of Hazard Risk \& Resilience, Durham University. I thank Dr Folarin Akinbami, Dr Orkun Akseli and Professor Andrew McGee for very useful comments on previous drafts of this paper, and Dr Sarah Jhumka for invaluable assistance in the preparation of the diagrams. Errors remain my own.
} 


\section{A - Introduction}

This article investigates some of the legal challenges that emerged as a consequence of the rapid evolution of financial markets in the period leading up to the 2008 meltdown. It is in particular concerned with the process of disintermediation ${ }^{2}$ which is defined as the trend that allowed firms to access capital markets directly, without the intermediation of banks, and at lower costs than issuing corporate bonds. ${ }^{3}$ The development of this process rested on new transactional models, identified with securitisation and in more recent years with its more innovated successors, most notably collateralised debt obligations (CDO).

In the aftermath of the global financial crisis (GFC), financial innovation and structured finance have been identified among the engines of the subprime crisis and more generally as areas that needed regulatory intervention. ${ }^{4}$ More complex forms of CDOs in particular (synthetic ones and CDO squared) were found to contribute to an overall mispricing of risks that were being sold to investors and to a more general opacity in debt capital markets. ${ }^{5}$ These concerns materialised in the post-crisis years as a number of disputes arose in connection with the sale of complex financial products, both in the UK and the US. Following the defaults and/or downgrades of debt products sold and marketed by investment banks, a number of actions have been brought by commercial banks, insurers and other institutional investors who sought redress for the losses suffered from the purchase of what proved to be toxic debt securities. ${ }^{6}$

This article focuses on assessing the degree of accountability of the main actors involved in the structuring and management of CDOs. This is done by looking at the duties

\footnotetext{
2 S.L. Schwarcz "Framing Address: A Framework for Analyzing Financial Markets Transformation", Seattle University Law Review, 36:299 2013, p.303.

${ }^{3}$ Ibid. This occurs through the process identified as securitisation, whereby originators pool receivables which are transferred to an SPV that in turn issues securities (backed by those receivables) to investors in debt capital markets.

${ }^{4}$ Lord A. Turner "The Turner Review: A regulatory response to the global banking crisis", FSA Discussion Paper, March 2009, p.14.

${ }^{5}$ Ibid.

${ }^{6}$ For a review of some specific legal issues emerged in some recent cases, see V. Bavoso "HSH v UBS: Lessons from New York”, 377 Butterworth Journal of International Banking and Financial Law, Vol.28 N.6, 2013.
} 
owed respectively by SPV directors, trustees and asset managers, and the actions that can be brought ex post by investors. The article attempts to look at both UK and US scenarios.

This line of enquiry has become increasingly urgent in the post-crisis years for two main reasons. Firstly, there was a surge of speculative transactions in pre-crisis years, where structured products were created for the only purpose of extracting rents from investors. These have been epitomised by the circumstances of the Goldman Sachs Abacus $\mathrm{CDO}^{7}$, which reignited the debate as to whether fiduciary liability should be applied to mitigate the information asymmetry that persists in these transactions. Secondly, the initiative undertaken at EU level to revive the securitisation market is largely premised on the definition of what "high quality securitisation" should encompass. ${ }^{8}$ While much debate between industry and policy-makers has revolved around this fundamental definition, there is still disagreement on whether CDOs and synthetic transactions should be included in the above definition. ${ }^{9}$ Questions of transaction standardisation also surfaced in this consultation process. Standardisation would be most relevant in the effort to make transactions more transparent and perhaps simplify the chain of claims and counterclaims that characterise securitised products. As will be discussed throughout this article, Special Purpose Vehicles (SPVs) stand as separate legal entities in the middle of the securitised structure and this creates difficulties in establishing a legal relationship (and liabilities) between the parties who manage the transaction (originators and sponsors) and investors.

This article will proceed as follows. Section B of this article analyses the complexity of synthetic CDOs in light of the legal issues that emerge in these transactions, using the Abacus CDO as illustration. Section $\mathrm{C}$ provides a close analysis of the legal duties and potential liabilities in CDOs, highlighting specifically the position of SPV directors, trustees

\footnotetext{
${ }^{7}$ SEC v. Goldman Sachs 10-cv-3229 (2010) United States District Court, Southern District of New York.

${ }^{8}$ BoE, ECB "The Case for a Better Functioning Securitisation Market in the European Union", Discussion Paper, May 2014.

${ }^{9}$ For a discussion, see V. Bavoso "High Quality Securitisation and Capital Markets Union - Is it Possible?", Convivium, forthcoming 2016.
} 
and asset managers. This discussion is completed in section D which explores other possible avenues to bridge the accountability gap, namely fiduciary law and the law of misrepresentation. Section E concludes.

\section{B - Legal problems and risks in complex structured transactions: synthetic CDO}

The increased availability of credit in the years before the GFC pushed investment banks and other financial intermediaries to search for new types of debt instruments and channel investors' demand towards the creation of new products. CDOs were introduced in the late 1980s as a natural development of securitisation and in fact replicated it as far as the main structure of the transaction is concerned. The main innovation related to the slicing of the security into "tranches" of different credit quality and subordination, whereby each tranche would carry a different risk and rate of return, appealing investors with different risk appetite and providing therefore a more customised product than securitisation. ${ }^{10}$ CDOs also contributed to creating more liquidity - and therefore a less expensive way to participate in the capital market - because typically the assets repackaged in a CDO are existing debt instruments. $^{11}$

This section provides an overview of the main transactional features of CDOs and it highlights the complex legal relationships that arise in connection with more innovated synthetic structures. These are further illustrated through the study of the Abacus CDO.

CDOs can be categorised into two different families, which expose different sets of legal issues: "cash-flow" CDO and "synthetic" CDO. The former reflects the legal structure of securitisation, centred on the "true sale" of assets between the originator and the SPV (see

\footnotetext{
${ }^{10}$ See D. Lucas, L. Goodman, F. Fabozzi "Collateralised Debt Obligation and Credit Risk Transfer", Yale ICF Working Paper No.07-2006. The CDO structure will have at the top a layer of most secured AAA tranche that enjoys a higher degree of subordination, followed by mezzanine tranches and then at the bottom by highly levered unrated equity tranches which will absorb losses in case of default but will also attract high yields.

${ }^{11}$ A. Buckley "Financial Crisis: Causes, Context and Consequences", Pearsons 2011, p.79.
} 
diagram 1). ${ }^{12}$ This serves the purpose of avoiding risks of recharacterisation of the transaction as secured financing ${ }^{13}$ and it corroborates the SPV's bankruptcy remoteness, which avoids risks of assets consolidation between originator and SPV in the event of insolvency. ${ }^{14}$ The SPV will issue different tranches of securities using the proceeds of the bond issue to finance the purchase of the assets. Investors are paid, according to the seniority of the tranche, with the cash-flow generated by the underlying assets. ${ }^{15}$

The advantages of cash-flow CDOs consist in providing financial institutions with a mechanism for balance sheet and risk capital relief through the sale of assets off-balance sheet and the release of risk capital held by the originator against the assets. Cash-flow structures remain more advantageous in this sense because of the off-balance sheet role played by the SPV. ${ }^{16}$

Synthetic CDOs represent a more drastic innovation of securitisation because the traditional assignment of assets is replaced by credit derivatives. The credit risk transfer is not achieved by transferring assets to the SPV, but by entering into credit default swaps (CDS) with a protection seller (see diagram 2). Another key development of synthetic transactions is represented by the different function played by the SPV. Since there is no transfer of assets from the originator, CDSs are instead entered into between the originator and the SPV to achieve the risk exposure to a specific pool of assets. ${ }^{17}$ Moreover, securities in synthetic CDOs are serviced out of the cash-flow derived from CDS contracts, instead of the reference

\footnotetext{
${ }^{12}$ P. Wood "Project Finance, Securitisation, Subordinated Debt", Sweet and Maxwell 2007, ch.8, where a "true sale" is defined according to: 1) liability for the assets which should pass to the buyer, 2) exclusive control over the assets that should again be with the buyer, 3) non revocability of the sale in case of buyer's insolvency.

${ }^{13}$ See A. Berg, "Recharacterisation after Enron", Journal of Business Law, 205-238, 2003.

${ }^{14}$ Supra Wood 2008, p.469-471. Bankruptcy remoteness is achieved also through governance arrangements, namely, limited exposure of the SPV because of the limited business purpose, non-petition agreements from creditors, limited recourse to available assets. See Slaughter and May "Model Guide to Securitisation Techniques", February 2010, p.6 and 11.

${ }^{15}$ F.J. Fabozzi "Introduction to Structured Finance", Wiley Finance 2006, p.122.

${ }^{16}$ Supra Fabozzi 2006, p.120. Originators maintain the opportunities to gain fees for managing the asset pool and capture the spread between the return on the collateral and the cost of borrowing to buy it.

${ }^{17}$ Supra Slaughter and May 2010, p.19.
} 
asset pool. ${ }^{18}$ Hence there is the creation of a security backed by a synthetic exposure (the CDS) rather than real assets.

Within this scheme the SPV acts as swap counterparty in the CDS contract ${ }^{19}$, whereby it agrees to sell credit protection on the reference pool of assets for the benefit of the institution holding the assets, namely the originator/sponsor. ${ }^{20}$ The SPV will issue creditlinked notes to investors ${ }^{21}$, creating therefore an exposure to the risk attached to the reference assets without the title of the assets having passed to it. ${ }^{22}$ By issuing credit-linked notes to investors, the SPV does not retain the credit risk acquired as protection buyer, but it passes that risk on to investors in the capital markets. ${ }^{23}$

A number of features have made synthetic structures more convenient and popular in the pre-crisis years. ${ }^{24}$ Firstly, synthetic CDOs allow the transfer of risk of more assets than under traditional securitisation, because there is no actual sale of assets and no legal requirements for the originator to hold the assets whose credit risk is securitised. ${ }^{25}$ Moreover, securities issued in synthetic structures are serviced out of the cash-flow generated by the CDS and this entails that synthetic CDOs are employed to securitise the credit risk of assets whose cash-flow is less predictable. ${ }^{26}$ Thirdly, synthetic CDOs provide investors with the

\footnotetext{
${ }^{18}$ J.J. De Vries Robbe, P. Ali "Synthetic CDOs: The State of Play", Journal of International Banking Law and Regulation, 21(1) 2006, p.13.

${ }^{19}$ In essence, the owner of assets (protection buyer) transfers the credit risk of an asset pool to another entity (protection seller) while the actual ownership of the reference obligations remains with the protection buyer. See E. Uwaifo "key Issues in Structuring a Synthetic Securitisation Transaction - A European Perspective", 98 Journal of International Banking Law, 16, 2001.

${ }^{20}$ The SPV will in turn transfer the credit risk acquired as protection seller to another financial institution through another derivative instrument. Supra De Vries Robbe, Ali 2006, p.15.

${ }^{21}$ Credit-linked notes are typically employed in funded credit derivatives when the investor in the note is the protection seller and is making an upfront payment to the protection buyer when buying the note. The protection buyer therefore is the issuer of the note, and the buyer of the note is the protection seller. Supra Fabozzi 2006, p.181-182.

${ }^{22}$ Supra Slaughter and May 2010, p.19.

${ }^{23}$ Ibid, p. 14.

${ }^{24}$ Supra Buckley 2011,p.79.

${ }^{25}$ Supra De Vries Robbe, Ali, 2006, p.13.

${ }^{26}$ Ibid.
} 
opportunity to buy tailor-made products, which are generally cheaper and faster to issue because of the simplified legal requirements. ${ }^{27}$

Another critical feature of synthetic CDOs is the greater leverage they create. The absence of the true sale means that there are no constraints on the level of exposure to the securitised assets. This in turn entails that the value of specific tranches in CDOs can sometimes be ten times the aggregate value of the underlying assets. ${ }^{28}$

The obvious drawbacks of these transactions are the limited effect of risk capital relief and the nullified balance sheet relief. The alchemy of these innovative structures however allowed financial institutions to purchase vast amounts of existing debt securities and book immediate profits by repackaging and selling them to investors, while remaining unconcerned about whether underlying debts were likely to be repaid. This process further contributed to erode monitoring incentives on the part of originators in originate-to-distribute chains. Investment banks in particular were focused on structuring transactions to obtain triple-A ratings, which were the result of complex correlation formulas applied for the packaging of the underlying assets, rather than their quality. ${ }^{29}$

The overwhelming mispricing of credit flowed from two further problems. Firstly, CDOs were characterised by the complexity of the assets that were sold to investors. This is because the repackaged pools comprised heterogeneous assets which were not accurately valued by credit rating agencies. ${ }^{30}$ Secondly, the complex legal relationships arising in

\footnotetext{
${ }^{27}$ S. Clarke, E. Lamberton "Collateral Damage: A Reference Pool of CDO Claims", Journal of International Banking Law and Regulation, 2010, 25(7), p.315.

${ }^{28}$ Supra De Vries Robbe, Ali, 2006, p.13.

${ }^{29}$ A. Johnston "Corporate Governance is the Problem, not the Solution: A Critical Appraisal of the European Regulation on Credit Rating Agencies", 395 Journal of Corporate Law Studies, Vol.11 2011, p.407. This is exemplified by CDOs receiving AAA ratings even though the underlying assets were worth B or less.

${ }^{30}$ S.L. Schwarcz "Regulating Complexity in Financial Markets", Washington University Law Review, Vol.87:211, Issue 2, 2009, p.216. Credit Rating Agencies insisted in the pre-crisis years in employing the same rating methodologies for both corporate bonds and structured ones, neglecting the fundamental differences between the two. See on this ESME's report to the European Commission "Role of Credit Rating Agencies", June 2008, p.3. More recently asset complexity has been recognised by the ECB and the BoE among the problems associated with the lack of transparency in securitisation and the concentration of risks, see BoE/ECB "The Case for a Better Functioning Securitisation Market in the EU", Discussion Paper May 2014.
} 
connection with synthetic exposures allowed sophisticated investors and transaction sponsors to manipulate the pricing of collateral thanks to their inside knowledge. This also translated in perverse conflicts of interest that led to incentives to destroy firms' value in order to make short positions worth more by triggering CDS payments. ${ }^{31}$

The detrimental effects of the overabundance of securitised credit became clear after the GFC. The development of synthetic transactions, based largely on derivatives designed to mimic the performance of particular mortgage pools, increased the level of risk-taking (through increased levels of leverage) in the financial sector without facilitating at the same time the access to the housing market. Moreover, the use of these structured products to hedge risks resulted instead in the same risks being magnified and spread across the financial system $^{32}$, either dumped to unaware investors, or concentrated in systemic institutions. This process proved to be particularly detrimental for those at the end of the transaction chain. The recent wave of litigation based on claims brought by commercial banks that had bought CDOs highlights a number of regulatory issues, most notably: the inadequate disclosure of risks, misrepresentation, and conflicts of interest of sponsoring investment banks. The facts of the Goldman Sachs Abacus CDO (see diagram 3) provide an apt illustration of these complex legal relationships and the resulting problems.

\section{1 - The Abacus CDO}

In 2010 the US Securities and Exchange Commission (SEC) brought charges against Goldman Sachs (and one employee, Fabrice Tourree) for materially misleading statements and omissions made in connection with a synthetic CDO structured and marketed by

\footnotetext{
${ }^{31}$ See H. Sender "Hedge-Fund Lending to Distressed Firms Makes for Gray Rules and Rough Play", Wall Street Journal, July 18, 2005. Most prominent is the manipulation of a synthetic CDO structured by Goldman Sachs, where a hedge fund with a short position in the CDO participated in the selection of the CDO's portfolio. Supra SEC v. Goldman Sachs 2010.

${ }^{32}$ See E. Avgouleas "The Global Financial Crisis, Behavioural Finance and Financial Regulation: In Search of a New Orthodoxy”, 23 Journal of Corporate Law Studies, Vol.9 Part 12009.
} 
Goldman Sachs for a number of investors. ${ }^{33}$ The key facts of the case revolved around the role played by the collateral manager (ACA Management LLC, with experience in analysing risks in RMBS) and a hedge fund (Paulson \& CO Inc) in the selection of the asset portfolio which comprised subprime residential mortgage-backed securities (see diagram 3). One peculiar aspect of this transaction was that the hedge fund contributed to structure the CDO and in particular to select the reference portfolio, in whose equity tranche it invested. The hedge fund however shorted its position in the CDO by entering into CDS contracts with Goldman Sachs that would have yielded profits in case of downgrade of the reference portfolio. What was particularly controversial in this transaction was that the hedge fund's position and economic interest in the CDO remained unknown to investors and allegedly also to the collateral manager. ${ }^{34}$

The investors in the CDO - among which large institutions such as ABN Amro and IKB - relied on ACA's independent role in verifying the portfolio they were purchasing, and were not aware of Paulson's adverse economic interest. They therefore alleged to have been misled, through Goldman's false representations and omissions, to invest in products they would not have otherwise purchased. ${ }^{35}$

The Abacus CDO has come to epitomise a perverse modus operandi - recurring in a number of cases discussed later in this article - diffused among large financial institutions with inside knowledge of deteriorating market conditions. This consisted in: 1) investing in the equity tranche to gain investors' confidence in the CDO; 2) secretly shorting the CDO's senior tranches by entering into a CDS. This recurring strategy confirms two problems: firstly, from an economic perspective the payments on the CDS tend to be greater than any losses suffered from the failure of the equity tranche. This means that hedge funds (and eventually

\footnotetext{
${ }^{33}$ SEC v. Goldman Sachs 10-cv-3229 (2010) United States District Court, Southern District of New York.

${ }^{34}$ This later led to an action brought by ACA against Goldman Sachs (discussed later in this article).

${ }^{35}$ See R. Tomasic and F. Akinbami "The Role of Trust in Maintaining the Resilience of Financial Markets", 369 Journal of Corporate Law Studies Vol.II, part 2, 2011, p.387.
} 
sponsors) can have a short-term value-destructive incentive in the selection and management of collateral. Secondly, from a legal perspective, the selection and management role of the CDO portfolio remains poorly defined with different parties performing these functions (sponsors, hedge funds, asset managers) and unsuitable rules to protect investors.

The action brought by the SEC was directed against Goldman Sachs and its employee Tourree who was responsible for the preparation of the marketing material related to the $\mathrm{CDO}$ and knew of Paulson's role and interest in the transaction. ${ }^{36}$ No action however involved the collateral manager or the hedge fund, whose position in the transaction remained undefined in the action brought by the SEC. The case was eventually settled by Goldman Sachs, chiefly to interrupt the reputational blow inflicted by the media ${ }^{37}$, rather than because of risks of incurring liability, which, as will be discussed in the next sections, may not have been triggered at all.

\section{C - Regulating accountability in CDO transactions}

A number of recent UK and US cases have shown that there are difficulties in firstly, identifying the parties in structured transactions who should be accountable for the structuring and marketing of complex securities, and secondly, establishing liability against them. The context of this discussion is that of "dynamic" transactions ${ }^{38}$, where the reference pool of assets moves in concert with maturity liabilities or with the occurrence of credit events that require restructuring the asset portfolio in order to maintain eligibility criteria. ${ }^{39}$ Key responsibilities therefore revolve around the initial selection of the assets and their subsequent substitution as the transaction evolves. This article recognises three actors that

\footnotetext{
${ }^{36}$ Supra SEC v. Goldman Sachs (2010).

${ }^{37}$ See for instance: The Economist "Sachs and the Shitty", 29 April 2010.

${ }^{38}$ See D. Long "Converging Developments in ABCP Conduits and SIV Markets" in "Asset Securitisation and Synthetic Structures: Innovations in the European Credit Markets" edited by E. Watson and J. Carter, 2006, p.124.

${ }^{39}$ Supra De Vries Robbe, Ali, 2006, p.16.
} 
can be singled out for the role they play in the management of these complex transactions (see diagram 4).

Firstly, it is fairly straightforward to single out SPV's directors (it is the vehicle that issues notes to investors) and the originator/sponsor's directors. The sponsor in particular will play a prominent part in structuring the $\mathrm{CDO}$ and marketing it to investors but as the analysis will show, the configuration of sponsors' accountability to investors is very remote.

Secondly, trustees (financial institutions specialised in these services) are appointed in structured transactions as controllers of bondholders' rights and represent them for the purpose of enforcing their rights. ${ }^{40}$ It is worth remembering that typically investors in securitised products are granted a security interest over the assets of the SPV, which are then held on trust by the security trustee in the interest of investors (see diagram 4).

Thirdly, asset or collateral managers are consulting firms that are mostly involved in dynamic/managed securitisations and are responsible for selecting the assets and substituting them as the transaction evolves. Their role can be compared to that of gatekeepers as they perform a controlling function on the selection of the asset portfolio. In addition, sponsors and underwriters resort to collateral managers because of their "branding" function that contributes to the marketing and placement of the securities. ${ }^{41}$

The analysis of possible duties and liabilities that can be attributed to the above actors needs to take account of the central role played by the SPV in structured finance. As can be seen from diagrams 1, 2 and 3, structured transactions are characterised by the interposition of the SPV between the originator/sponsor and the investors. SPVs are corporate entities ${ }^{42}$ set up by the originator of receivables or the transaction sponsor, often in offshore jurisdictions

\footnotetext{
${ }^{40}$ G. Thomas and A. Hudson "The Law of Trust" OUP 2010, p.1370.

${ }^{41}$ See SEC v. Goldman Sachs 10-cv-3229 (2010) United States District Court, Southern District of New York.

${ }^{42}$ SPV s can be either companies or trusts; in the latter, a trustee is appointed over the assets held in the SPV; in a company, a trustee will act as custodian/manager of the assets. A. Hudson "The Law of Finance", Sweet and Maxwell 2013, p.1299; S.L. Schwarcz "Commercial Trusts as Business Organizations: Unravelling the Mystery”, 559 Business Lawyer Vol.58, Feb.2003, p.564.
} 
due to favourable tax conditions. The special purpose for which they are incorporated consists in the issue of notes to investors, which funds the purchase of a pool of assets from the originator (or the payment under the CDS in synthetic CDOs). What is particularly relevant is that SPVs are set up as bankruptcy remote from the originator through a number of legal covenants and governance arrangements. ${ }^{43}$ Bankruptcy remoteness is typically achieved by ensuring that the SPV's assets are not subject to substantive consolidation with the originator's estate in the event of its insolvency, and by agreeing non-petition clauses with noteholders (effectively the only SPV's creditors) which will screen the SPV from insolvency proceedings.

The task of establishing accountability in CDOs is problematic because of long and complex transaction chains and because the entity that issues securities to investors is the SPV, while the effective management of the reference asset portfolio rests somewhere else (chiefly, originator/sponsor' directors and asset manager - see diagram 4).

\section{1 - Directors}

It was mentioned in the previous section that in order to corroborate bankruptcy remoteness, SPVs are set up with independent directors who are in charge of the entity's special business purpose. Overall, SPV directors have residual decision-making powers and are not in charge of the central tasks related to the selection, management and restructuring of the asset portfolio. They tend to be professionals specialised in directorial services and much of their discretion in matters related to the transaction is anyway curtailed by contractual provisions that require them to resort to external professional advice and that also screen them from potential liability to secured creditors. ${ }^{44}$

\footnotetext{
${ }^{43}$ Slaughter and May "Model Guide to Securitisation Techniques", February 2010, p.6; namely, capitalisation, books and accounts, no commingling of assets, independent director.

${ }^{44}$ Clifford Chance "New Beginnings", 2009, p.17.
} 
A discussion about duties to creditors (the noteholders) owed by SPV directors would be almost irrelevant for the purpose of establishing accountability. As explained earlier, there is not much in the remit of SPV directors that could cause a breach of their duties to noteholders: the misrepresentation of the assets' risks and more generally the way in which the CDO is structured and managed depend chiefly on the sponsor/originator and on the asset manager, while trustees are in charge of post-default restructuring operations. Furthermore, the application of s.214 of the Insolvency Act 1986 in the UK - which could provide a retroactive mechanism for the liquidator to require directors of insolvent companies to contribute towards the funds available to creditors - is very difficult to configure because the SPV is protected, through non-petition agreements, from insolvency proceeding brought by its creditors (noteholders). Even in the event of the SPV's default, s.214 requires that the SPV directors ought to have recognised that there was no reasonable prospect of avoiding insolvent liquidation, and failed to take all the reasonable steps to minimise the loss to investors. ${ }^{45}$ As explained though, the managerial powers that could potentially minimise the loss to investors do not rest within the remit of SPV directors. Neither does s.214 provide an outright obligation on the part of directors to act in the interest of creditors. ${ }^{46}$

Directors' accountability to noteholders is anyway difficult to construct under English law (when that is the relevant jurisdiction) because s.172 of the Companies Act $2006^{47}$ reiterates in essence shareholder value as the guiding principle of corporate management without encompassing any statutory duty to creditors. ${ }^{48}$ Similarly in the US, Delaware courts have made clear that directors' duties are owed to shareholders, not only when the company

\footnotetext{
${ }^{45}$ S.214, provided directors ought to have recognised that the company had no reasonable prospect of avoiding insolvent liquidation and failed to take all reasonable steps to minimise the loss to creditors.

${ }^{46}$ Explanatory Notes to the CA 2006, para 332.

${ }^{47}$ Under s.172, the main duty is to act in a way that is most likely to promote the success of the company for the benefit of its members as a whole. S.172 requires directors only in certain circumstances to act in the interest of creditors, which becomes prevalent only when the company is insolvent or nearing insolvency. See DTI "Modern Company Law for a Competitive Economy: Final Report", 2001, clause B3 and B19.

${ }^{48}$ See A. Keay “Company Directors' Responsibilities to Creditors", Routledge 2007, part D.
} 
is solvent, but crucially also when it is in the vicinity of insolvency. ${ }^{49}$ It is only after insolvency is triggered that creditors acquire a different stand ${ }^{50}$, and as said this is unlikely to happen because noteholders are contractually prohibited from petitioning for the SPV's insolvency. It is worth noting in this respect that SPVs have an atypical capital structure because they are chiefly funded with debt and are only thinly capitalised with shares normally held by a trust or a charitable foundation. Yet despite the lack of shareholding and their special purpose, they are governed by the same set of duties as other private companies.

As a final point, it needs to be remembered that SPVs are broadly employed as bankruptcy remote entities in commercial and financial practice in a variety of situations. These range from asset finance and real estate finance, to project financing and leveraged buy-outs. Although their function may be similar (as certainly is the underlying aim to isolate a pool of assets and their associated risk), the structure of securitisation-type transactions is fundamentally different and it presents more problematic avenues to establish directors' accountability. In Roberts v. Frohlich ${ }^{51}$ for instance, the UK court found that the SPV directors were in breach of their duties for letting the company continue the business even when they knew that this was speculative and leading to failure. The s.214 claim was successful because, despite the very high test which is set in these cases, directors' overoptimism had led to poor management to the detriment of creditors, justifying therefore misfeasance and breach of duty. ${ }^{52}$ It is however very unlikely that the directors of a structured finance SPV could be caught under the same breach of duties because of the narrowness of the special purpose; in Roberts $v$. Frohlich the SPV was involved in a property development business.

\footnotetext{
${ }^{49}$ In this sense Credit Lyonnais Bank Nederland, NY v. Pathe Communication Corp. (1991 Del Ch WL 277613).

${ }^{50}$ In this sense Quadrant Structured Products Ltd v. Vertin et al (2015 Del Ch May), where the court clarified that the shift in creditors' position is not so much about the duties owed to them by directors, but about the right to bring derivative actions for breach of fiduciary duties.

${ }^{51}$ [2011] EWHC 257 (Ch).

52 J. Payne, “Directors Duties”, All England Annual Review 2011, Section 4 Company Law, para 4.26.
} 
In conclusion, a breach of directorial duties is very difficult to configure in the context of structured finance transactions for SPV directors. The activities for which noteholders would need to establish accountability are conducted by the originator/sponsor's directors and against them investors will attempt actions for misrepresentation or breach of fiduciary duties, which will be examined in section D. Due to the interposition of the SPV as issuer of the structured products, the originator/sponsor's directors are not bound by any specific duties to investors.

\section{2 - Trustees}

The role of trustees in structured transactions emerged from the practice of issuing bonds to investors whereby a trustee would be nominated to represent bondholders' interests. ${ }^{53}$ The appointment of a trustee has the function of coordinating the interests of all bondholders in accordance with the term of the bond and the trust deed, in the event of a conflict between different classes of bondholders; in the case of a secured transaction (like most structured bonds) the security trustee represents the interest of secured creditors. ${ }^{54}$ Trustees therefore act in a position alike to that of a referee, ensuring the proper performance of the bond through their discretionary powers to enforce obligations under the trust deed. ${ }^{55}$

It is worth stressing that trustees are not responsible for the way in which CDOs are structured or managed and much of the litigation against them generated from claims related to the way in which proceeds should be distributed among different tranches. Investors therefore could have an avenue for redress under the indenture agreement which governs (in

\footnotetext{
${ }^{53}$ Supra Thomas and Hudson 2010, p.1397; it is observed that the role of trustees in bond issues is close to that of a regulator for that issue with its duties stipulated in the documentation. It is a listing requirement to appoint a trustee with powers to act on behalf of all bondholders and with continuous involvement in the issue. See also P. Rawlings "The Changing Role of the Trustee in International Bond Issues", Journal of Business Law 43, 2007, p.47. When the bond is secured, the trustee is appointed to hold the security for the bondholders and eventually to enforce it and distribute related proceeds.

${ }^{54}$ Supra Rawlings 2007 p.48; Thomas and Hudson 2010, p.1391,1396.

${ }^{55}$ Supra Rawlings 2007, p.49,50. In doing so trustees often have powers to waive minor breaches or agree to modifications of the terms of the bond without bondholders' consent, as long as they are satisfied that there is no material prejudice to bondholders' interest.
} 
an often complex an intricate manner) the way funds are collected and distributed among noteholders. ${ }^{56}$ Trustees' general powers in the context of CDOs are therefore triggered in post-default situations and before then their role remains passive ${ }^{57}$ After an event of default occurs, trustees are empowered to both bring proceedings under the term of the bond, and to ensure payments to investors. It is in this specific context that their powers need to be analysed together with their eventual liability to investors.

One initial problem related to trustees' role in structured finance is the extent of their discretion and powers. While the meaning and extent of their general investment powers was brought on a statutory footing in the UK with the Trustee Act 2000 (s.3 in particular), it is necessary to point out that professional trustees acting in the context of structured transactions are not likely to be regulated by the Act. They typically agree to take the job only once their powers and obligations are specified in the transaction documents, where exclusions or limitations of their liabilities are agreed. ${ }^{58}$ In particular, the statutory duty of care and skill, shifted post-2000 from the standard of prudent man centred on caution ${ }^{59}$ to encompass a test of what is deemed reasonable under the circumstances, will not apply to professional trustees who contract out of statutory liability. ${ }^{60}$ In such cases, trustees' duties of care will be regulated primarily by the transaction documents, and residually by reference to the standard market practice and the standard market regulation. ${ }^{61}$ In essence, while the duty of care would translate, in contexts of structured transactions, in higher standards due to

\footnotetext{
${ }^{56}$ J. Bethel, A. Ferrell, G. Hu "Law and Economic Issues in Subprime Litigation", Harvard John C. Olin Centre for Law, Economics and Business, Discussion Paper No.612, 03/2008, p.29,30.

57 Supra Thomas and Hudson 2010, p.1387; S. Schwarcz "Structuring Responsibility in Securitization Transactions", 803 Capital University Law Review 40, 2012, p.810. Trustee will mainly be responsible to collect profits in the instruments which are paid to investors. In case of distressed transactions, trustees' involvement may start at an earlier stage.

${ }^{58}$ Supra Thomas and Hudson 2010, p.1423.

${ }^{59}$ Enshrined in old cases, most prominently: Learoyd $v$. Whiteley (1887) 12 App Cas 727.

${ }^{60}$ Supra Thomas and Hudson 2010, p.1425. Beneficiaries would need to prove that no reasonable trustee acting with care and skill would have acted so badly.

${ }^{61}$ See Bankers Trust v. Dharmala [1996] CLC 518, where the appropriate measure of the obligation was held to be found in the FSA rulebook.
} 
trustees' expertise ${ }^{62}$ and to noteholders' reasonable expectations ${ }^{63}$, transactions documents will exclude liability arising from a higher duty of care, from errors of judgement made in good faith, or from loss deriving from advice provided by lawyers and accountants. ${ }^{64}$ The US framework revolves around the obligation under the Trust Indenture Act $1939^{65}$ to act as a prudent person after an event of default occurs, in light of the purposes, terms and circumstances of the trust. Like in the UK, the extent of trustees' powers and their discretion is not clear and it gives rise to a number of uncertainties, especially in circumstances where trustees are called to balance the conflicting interests of different classes (or tranches) of noteholders. ${ }^{66}$

The key question related to the extent to which trustees can exclude liability has been addressed in the UK in Armitage v. Nurse where it was reiterated that "there is an irreducible core of obligations owed by the trustees to the beneficiaries and enforceable by them which is fundamental to the concept of trust". ${ }^{67}$ While this duty of good faith was envisaged as the minimum necessary obligation to substantiate a trust, it was also considered sufficient, which meant that a duty of care and skill was not to be intended as a core obligation. ${ }^{68}$ This was confirmed more recently in the Court of Appeal of Guernsey that stated that a trustee could rely on exclusion of liability arising from gross negligence. ${ }^{69}$ While exclusions of liability do

\footnotetext{
${ }^{62}$ See S. 1 Trustee Act 2000.

${ }^{63}$ This was firstly exemplified in Bartlett v. Barclays Bank [1980] Ch 515 with a distinction between prudent degree of risk and "hazard" where only the former was to be acceptable; and more recently in Nestle' $v$. National Westminster Bank [2000] WTLR 795, where the trustee's actions were measured in accordance with portfolio theory.

${ }^{64}$ Supra Thomas and Hudson 2010, p.1423; Supra Rawlings 2007, p.52.

${ }^{65}$ S.315c, 15 USC.

${ }^{66}$ On this, S. Schwarcz "Fiduciaries with Conflicting Obligations”, 94:1867 Minnesota Law Review, 2010.

${ }^{67}$ [1998] Ch. 241. It was held that a clause excluding a trustee's personal liability for gross negligence would be valid.

68 The issue as to whether professional trustees should be free to exempt themselves from liability has encountered mixed reactions; while the Law Commission suggested that this freedom should be constrained by law, the Financial Markets Law Committee opined that this approach would make trustees on the capital market reluctant to exercise discretion. Supra Rawlings 2007, p.53.

${ }^{69}$ Spread Trustee Co. Ltd v. Hutcheson [2011] UKPC 13. The amended act drawing a difference between negligence and gross negligence could not have retrospective effect.
} 
limit the scope of trustees' obligations, it needs to be remembered that principles of financial regulation cannot be excluded by agreement if one of the parties falls under the regulation. ${ }^{70}$

Trustees' role in CDOs is aptly illustrated by their power to accelerate the bond under an event of default, whereby they have to certify that, under the bond conditions, the event of default is materially prejudicial to noteholders' interests. The extent of trustees' powers in this context was defined in the Elektrim litigation where an event of default was alleged to have taken place and the transaction documents provided that thirty percent of bondholders could give notice to the trustee to accelerate ${ }^{71}$ On one of the main points in dispute, as to whether one of the events of default described in the deed also constituted a prejudice to bondholders, the court clarified that the trustee had broad discretionary powers to enforce bondholders' rights and it was also placed under an obligation to take action if so requested by thirty percent of bondholders (provided it was indemnified to its satisfaction). ${ }^{72}$ For the purpose of this discussion, the trustee in this situation is under a referee-type position, where it assesses whether a breach deserves to be actioned by investors, and to them the trustee is accountable as a fiduciary. ${ }^{73}$

Another example of how transaction documents shape the power and potential liability of trustees is the way in which they vote in situations of debt restructuring. In Citibank NA v. MBIA Assurance $S A^{74}$ the defendant (bondholder) was empowered under the transaction documents to direct the trustee (Citibank) on the proposed debt restructuring; the same documentation however also gave Citibank the general power to act with discretion and excluded any liability to bondholders. Since the proposed direction prioritised the interest of

\footnotetext{
${ }^{70}$ D. Hayton "The International Trust", Jordans 2011, p.668 and p.646, where the application of the "FSA Principles for Businesses" in this context is discussed in depth. Similarly, s.750(1) Companies Act 2006 mitigates the effect of these limitation clauses.

${ }^{71}$ Law Debenture Trust Corp v. Elektrim Finance BV [2005] EWHC 199 (Ch), and related litigation in Concord Trust v. Law Debenture Trust Corporation Plc [2005] UKHL 27.

${ }^{72}$ Concord Trust v. Law Debenture Trust Corporation Plc [2005] UKHL 27.

${ }^{73}$ A. Hudson "The Law of Finance", Sweet and Maxwell 2013, p.1029.

${ }^{74}$ [2006] EWHC 3215.
} 
the defendant to the detriment of other bondholders, Citibank sought direction from the court. It was held that the transaction documents gave the trustee a wide discretion in relation to the proposed restructuring, and that given the limitation of liability, there was no impediment in following MBIA's instructions ${ }^{75}$, giving therefore way potentially to what is referred to as "bondholders' warfare". ${ }^{76}$ Interestingly, the role of the trustee in the transaction was clear by reference to the transaction documents which defined Citibank's powers and obligations. This confirmed that the configuration of trustees' role in the transaction depends chiefly on parties' determination and bargain power.

The above conclusion is reflected in the US legal tradition where courts apply the "bond contract theory" which assumes that bond documents are negotiated at arms' length between sophisticated organisations, and therefore the terms of the contract govern the relationship. This entails that there are no duties owed to investors beyond those expressed in the documents. ${ }^{77}$ Under US law however, trustees' power and discretion is not as broad as it is in the UK and transaction documents cannot substantially limit individual bondholders' rights to the same degree they do in UK practice. ${ }^{78}$

In conclusion, trustees' role in CDOs is largely concerned with post-default scenarios and their powers and discretion are governed by transaction documents that limit their liability to investors. While trustees' involvement in the distribution of funds is crucial to govern conflicts among different classes of noteholders, the way CDOs are structured and in particular the way transaction documents are stipulated, does not seem to allow trustees to extend their power beyond this.

\section{3 - Asset managers}

\footnotetext{
75 Ibid.

76 S. Schwarcz "Fiduciaries with Conflicting Obligations", 94:1867 Minnesota Law Review, 2010.

${ }^{77}$ See L.E. Mitchell "The Fairness Rights of Corporate Bondholders", 1990, 65 New York University Law Review 1165

${ }^{78}$ Supra Mitchell 1990, p.1168. See also Trust Indenture Act 1939 s.315-316.
} 
Asset managers are typically entrusted with discretionary power to invest in financial instruments on behalf of clients. ${ }^{79}$ Their function in capital markets is rooted in the necessity to provide information intermediation between issuers of financial products on the one hand and buyers on the other. ${ }^{80}$ This is reflected in the account of the Abacus transaction where the service provided by the asset manager was described as vital for the flow of the transaction and instrumental in driving investors' decision to buy a portfolio of securities. ${ }^{81}$

In the context of CDOs the management role is crystallised in industry practice rather than in the law. Typically, assets managers are involved in the selection and replacement process of the assets that form the CDO's collateral and their role is aimed at providing an independent third-party expertise on the selection process in light of the placement and marketability of the $\mathrm{CDO}$ to investors. In dynamic transactions where the asset portfolio keeps changing with the maturity of underlying assets or with the occurrence of credit events, asset managers make sure that the portfolio eligibility criteria are maintained by replacing and substituting assets in the reference portfolio. In other words, the transaction sponsor (investment banks chiefly) will have an interest in having the manager's name on the transaction because this will certify the selection process in a gatekeeper-like fashion which in turn facilitates the branding and distribution of the CDO. ${ }^{82}$

As will be analysed in the following pages, the wave of post-crisis litigation involving structured transactions contributed to clarify the role of asset managers in CDOs and whether they can be held accountable to investors. ${ }^{83}$ In particular, questions related to their duties and

\footnotetext{
${ }^{79}$ D. Busch "Why MiFID Matters to Private Law - the Example of MiFID's Impact on an Asset Manager's Civil Liability”, 386 Capital Markets Law Journal, Vol.7, No.4, 2012, p.388.

${ }^{80}$ D.A. DeMott "Regulatory Techniques and Liability Regimes for Asset Managers", 423 Capital Markets Law Journal, Vol.7, No.4, 2012, p.425.

${ }^{81}$ Supra SEC v. Goldman Sachs 10-cv-3229 (2010). In the above situation it was reported that a German bank was unlikely to invest in the CDO liabilities without them having been analysed and selected by a reputable collateral manager.

${ }^{82}$ Supra Clifford Chance "New Beginnings", 2009, p.8.

${ }^{83}$ The first lawsuit launched against asset managers was probably SEC v. ICP Asset Management LLC 10-CV4791 (S.D.N.Y.) 2010, where the SEC filed an action against the CDO manager for having defrauded a number of the CDO investors. The action was settled in 2012.
} 
liability have arisen because of the conflicts of interest that asset managers can be subject to. This is due firstly, to the different tranches of the CDO which correspond to different types of investors with diverging interests (long and short); and secondly, to asset managers' market incentive ${ }^{84}$ to manage the asset portfolio in the interest of the sponsor and therefore of the equity tranche. ${ }^{85}$ This of course creates a risk incentive problem because the holder of an equity tranche will have an interest in increasing the riskiness of the reference portfolio ${ }^{86}$ or, as evidenced in the Abacus $\mathrm{CDO}$, to make a short position worth more by triggering the payment under a CDS.

With respect to the central question of establishing the type of duties and eventual liability arising for asset managers, these will largely depend on how transactions are documented. ${ }^{87}$ While duties may seem fiduciary in nature because of managers' position visà-vis investors, their extent is not clear. On the one hand, they manage the pool of assets for the ultimate interest of investors who are the ultimate recipients of their professional service, but on the other hand the only contractual relationship that asset managers have is with the issuer of securities, the SPV.

One possible action involving asset managers is the one that could be brought for breach of contract by the security trustee on behalf of the noteholders (providing the latter agree to indemnify the former). More specifically, this would be based on the breach of the indenture agreement ${ }^{88}$ (governed typically by UK or New York law) which stipulates the way

\footnotetext{
${ }^{84}$ Asset managers are normally paid their fees ahead of most investors in the CDO, but in many cases they own a piece of the equity tranche in order to align their interest with all investors in the CDO. See F. Koszeg "Will CDO Managers Be Held Accountable for their Role in the Financial Crisis?", Bloomberg Law, October 22, 2012. ${ }^{85}$ In this sense T. Mahlmann "Equity Friendly or Noteholder Friendly? The Role of Collateral Asset Managers in the Collapse of the Market for ABS-CDOs", Working Paper April 2012, p.13.

${ }^{86}$ Ibid, p.3.

${ }^{87}$ Bearing in mind that the relationship will in any case give rise potentially to contractual duties, duties in tort and statutory ones.

${ }^{88}$ This normally is a binding contract between the issuer and the noteholders. It governs the most important aspects of the bond, namely maturity date, timing of payments, as well as the terms and conditions of the bond. See http://www.investopedia.com/terms/i/indenture.asp.
} 
in which CDO funds are collected and distributed among various tranches. ${ }^{89}$ One possible example is provided by a lawsuit initiated in the US in 2007 by Deutsche Bank acting as CDO trustee and seeking the resolution of a dispute related to the way in which CDO proceeds had been distributed among different tranches. ${ }^{90}$ The key question of the case revolved around the interpretation of the indenture agreement as regards the payment distribution terms and more specifically whether a default had triggered an obligation of the security trustee to distribute proceeds held by the asset manager to tranche holders. ${ }^{91}$ The difficulty with the above case and other similar CDO-related disputes is that trustees face very complex and contradictory provisions in the indenture agreement with respect to the priority of proceeds to be applied after an event of default. ${ }^{92}$ Under these circumstances, as explained in the previous section, it is difficult to see trustees bringing this type of action because their discretion is likely to be hindered by the way their powers are limited in the trust deed. This dispute in essence was one between the noteholders and the trustee, regarding the interpretation of the indenture agreement, and it did not involve the asset manager directly, the difficulty with this type of claim being that asset managers are not a party to the indenture agreement. $^{93}$

Thus it is clear that the active role played by the asset manager is one that has an impact on the SPV which will suffer losses if the assets are not selected or managed properly. The question whether the SPV will be able to sue the asset manager depends chiefly on the terms of the contract between them. With respect to the SPV's title to sue the asset manager,

\footnotetext{
${ }^{89}$ J. Bethel, A. Ferrell, G. Hu "Law and Economic Issues in Subprime Litigation", Harvard John Olin Centre for Law Economics and Business, Discussion Paper No.612, 03/2008, p.29.

${ }^{90}$ Deutsche Bank Trust Company v. Lacrosse Financial Products LLC, 08-CV-0955 Supreme Court the State of New York, County of New York (2007).

${ }^{91}$ Ibid.

${ }^{92}$ See LaSalle Bank National Association, as Indenture Trustee, v. BNP Paribas, London Branch, et al, no. 08CV-6143 (United States District Court, Southern District of New York, 2008).

${ }^{93}$ In theory though, if the SPV is in breach of its obligations to pay noteholders what is due, or if there is an event of default, the security trustee then could enforce the security interest that it holds over the SPV's assets. These will include a right of action against the asset manager, so in essence the security trustee could in theory bring an action for breach of contract against the asset manager. This would of course also depend on the nature of the duty under the contract.
} 
this is clarified in the recent UK case (albeit not involving a structured transactions) Titan Europe 2006-3 Plc v. Colliers international UK Plc where the Court of Appeal had to assess whether the respondent (the SPV) had title to sue the valuer of a property for a negligent valuation. The valuer argued that the respondend did not have any causes of action against it, and even if it did, the loss would have been passed to the noteholders, as ultimate recipient of the service. The court held that the SPV, as purchaser of the underlying loan that had to be valued, was the correct party to bring an action, even though it had not suffered the ultimate loss. ${ }^{94}$

As stated earlier in this section, the SPV will have a cause of action against the asset manager and this will largely depend on the terms of the contract. In such instances, in theory it would be up to the SPV directors to bring such action (or the liquidator/administrator in the case of an insolvent SPV), but it is more likely that the security trustee may have an interest in doing so, in situations similar to the one arisen in the previously outlined case Deutsche Bank Trust Company v. Lacrosse Financial Products LLC. ${ }^{95}$

With respect to actions in tort for breaches of asset managers' statutory duties, these are premised on the existence of "proximity" between asset managers and investors, by virtue of which a duty of care can be established if bondholders relied on the service provided by the managers for their decision to invest. In the UK, such a breach is actionable by a private person and not by a sophisticated party ${ }^{96}$, therefore it is effectively precluded to most CDO investors. The proximity test anyway has traditionally resulted in uncertain outcomes with courts in the UK refusing in certain instances to establish a duty of care. ${ }^{97}$

\footnotetext{
94 [2014] EWHC 3106 (Comm), The SPV suffered a loss when it purchased the undervalued loan and it had responsibility under the contract to pass the amounts recovered in the action to the noteholders.

${ }^{95}$ 08-CV-0955 Supreme Court the State of New York, County of New York (2007). In essence, the SPV is the asset manager's client, and if the assets related to the claim against the asset managers are held on trust by the security trustee, the trustee can bring an action.

${ }^{96}$ Financial Services and Markets Act 2000, s.150.

${ }^{97}$ See for instance Arneson v. Arneson [1977] App. Cas. 405 (1975) where the proximity was recognised, and Caparo Industries V. Dickman [1989] 1 QB 653 (CA 1988) where the duty of care was not established. In the US, an exception is provided by the Second Circuit reversal of Bayerische Landesbank, NY v. Aladdin Capital
} 
Beyond this, collateral managers are subject at common law to the traditional "prudent person" standard in discharging their duty of care. ${ }^{98}$ This conservative approach however was geared to the needs to avoid speculation and to the preservation of assets. This rationale finds little or no reflection in today's context of complex transactions where managers' discretion has progressively increased, reducing courts' ability to review investment conducts and managers' compliance with their duties. More specifically, in the context of structured products, despite a tiered test of responsibility whereby advanced expertise implies a higher standard of care required ${ }^{99}$, investors would find it problematic to prove managers' inability to select the asset portfolio, because establishing lack of care in a market characterised by high complexity would be difficult. At the same time, such duties are also normally triggered when investors are classified as retail, whereas professional or sophisticated investors are assumed capable of looking after their interest. ${ }^{100}$

An illustration of how a breach of duty of care could be configured was provided in the UK case HSH Nordbank v. Barclays Bank ${ }^{101}$ where the claimant had purchased investment-grade tranches of a CDO ("Corvus") and alleged that the original assets were sold and replaced with poorly performing ones by the defendant (acting oddly both as sponsor and asset manager), thereby rendering the investment worthless. The claim revolved around Barclays' failure to adequately disclose the risks of purchasing the CDO interests; more specifically, with respect to Barclays' role as collateral manager, the action pointed to a breach of duty of care in the way the CDO was managed and also in inflating the value of CDO's assets in the marketing material. The lawsuit was eventually settled.

\footnotetext{
Mgmt., LLC, No. 11-4306 (2d Cir. 2012) where the interpretation of the portfolio management agreement led the court to infer that the parties intended the contract to benefit CDO investors and create obligations running from the asset manager to the investors whose relationship was deemed close enough to create a duty in tort.

${ }^{98}$ Exemplification of which can be found in Learoyd v. Whiteley (1887) 12 App Cas 727.

${ }^{99}$ See Re Waterman's Will Trust [1952] 2 All ER 1054, and Bartlett v Barclays Bank Trust Co Ltd [1980] 1 All ER 139.

${ }^{100}$ See Directive 2006/73/EC art.44. Similar exemptions exist traditionally also under UK and US law.

101 [2004] EWHC 1183 (Comm).
} 
Tortious liability and breaches of duty of care often derive from statutory regulations, which contribute to define this area of law. In the US, the duties of asset managers have been supplemented by a number of rules issued by the $\mathrm{SEC}^{102}$, while at EU level the enactment of MiFID ${ }^{103}$ and MiFID II ${ }^{104}$ provided a broader definition of portfolio management and financial instruments. ${ }^{105}$ The main obligations under MiFID revolve around an initial licensing requirement and a set of duties centred on avoidance of conflicts of interest and safeguard of clients' rights ${ }^{106}$, chiefly through the "best execution" provision. ${ }^{107}$

For the purpose of this enquiry, a central question falls on the provisions under MiFID and MiFID II which could regulate asset managers' conduct. With respect to MiFID, Article 19 makes specific reference to investment firms providing investment or ancillary services, having to act honestly, fairly and professionally in the best interest of clients. ${ }^{108}$ It also states that in doing so, appropriate information needs to be provided to clients about the proposed financial instrument and investment strategies in order to allow them to reach informed decisions. ${ }^{109}$ The Directive also burdens investment firms with a duty to acquire information concerning the client's relevant knowledge in the field and its investment objectives in order to enable the recommendation of the most suitable service/product and the related assessment by the client. ${ }^{110}$ Moreover, the "best execution" principle provided in article 21 creates an obligation on investment firms to obtain the best possible term/price when executing orders for clients. The application of these rules however, is premised on the existence of the "client

\footnotetext{
102 These mainly supplement the Investment Advisers Act 1940.

${ }^{103}$ EU Directive 2006/39/EC [2004].

${ }^{104}$ EU Directive 2014/65/EC [2014]. MiFID II was designed to enhance the conflict of interest management, especially in the context of large-scale proprietary trading and securitisation. See N. Moloney "EU Securities and Financial Markets Regulation", Oxford University Press 2014, p.371.

105 Supra DeMott 2012, p.424.

${ }^{106} \mathrm{MiFID}$, art.5; and art.9-13.

${ }^{107}$ Ibid, art. 21.

${ }^{108}$ MIFID Directive 2004/39/EC, art.19(1). This can be seen in conjunction with the "no conflict of interest rule" expressed in art.18.

${ }^{109}$ Ibid, art.19(3).

${ }^{110}$ Ibid, art.19,(4),(5). This provision can also be seen in conjunction with art.25 which mandates an obligation to maintain integrity and report details of relevant transactions.
} 
relationship", which in a CDO will exist between the asset manager and the SPV by virtue of the portfolio management agreement. ${ }^{111}$ As explained earlier, it will be the security trustee holding the assets for the interest of noteholders, who may have a right to bring an action.

MiFID II was introduced with a view to enhancing the conflict of interest regime through a number of interlocking requirements revolving around organisational and disclosure obligations. ${ }^{112}$ These represent a higher standard than MiFID as they apply regardless of clients' classification and are not dependent on the existence of a fiduciary obligation. ${ }^{113}$ MiFID II also provides an overarching fair treatment obligation consisting in a duty to act honestly, fairly and professionally in the best interest of clients when providing investment services. ${ }^{114}$ This is coupled with conduct rules related to the quality of the advice and the suitability rule. This requires the investment advisor to obtain necessary information on the client's knowledge and experience in investment, relevant to the product, and on the client's ability to bear losses and tolerate risks. ${ }^{115}$ The conduct regime however does not apply to order execution services provided to eligible counterparties, reflecting in this way the arm's length assumption that characterises wholesale transactions. ${ }^{116}$

As it is discussed below, the implementation and enforcement of the above provisions is difficult. This is so primarily because of the onerous causal connection that needs to be established to prove managers' breach of duty, and secondly because MiFID has not resulted in a uniform approach across the EU to this delicate area of investor protection. ${ }^{117}$ More importantly for the purpose of this enquiry, MiFID II failed to set adequate standards as

\footnotetext{
${ }^{111}$ MIFID Directive 2004/39/EC, art.4(10).

112 Respectively: art.16, which prescribes firms to maintain effective organisational and administrative arrangements to prevent conflicts of interest that affect clients; and art.23, which prescribes firms to take all appropriate steps to identify, prevent and manage conflicts of interest arising in the context of the service they provide.

${ }^{113}$ Supra Moloney 2014, p.373.

${ }^{114}$ Art.24 MiFID II. This also introduces provisions concerning the independence of the investment advice and prohibitions of inducement.

${ }_{115}$ Art.25(2).

116 Art.30.

${ }^{117}$ Supra Busch 2012, p.409, where it is observed that MiFID II has also missed the opportunity to clarify the proof of causation in cases of breach of duties of information and duties to warn under MiFID.
} 
regards conflicts of interest and monitoring of risk in the more specific context of securitisation-type products. ${ }^{118}$ It also needs to be borne in mind that there are different approaches to enforcement across jurisdictions and two different dimensions to it, namely public and private. The former relies on regulatory authorities that are prone and institutionally equipped to bring actions (chief example would be the US SEC), while the latter normally implies regulators that either do not possess the institutional powers to enforce (ESMA in the EU), or do not have a culture of interfering with market practices (the old UK FSA).

The atypical legal position of asset managers entails that some key managerial phases in structured transactions remain open to accountability deficits. This pertains primarily to the way in which assets with different risks are selected and replaced in the portfolio, the redirection of cash-flows from junior to senior noteholders and the overall risk to which some CDO tranches are exposed. ${ }^{119}$ The accountability gap is also due to the fact that in the past, because of the difficulties analysed earlier in this section, asset managers have hardly been involved in investors' claims in relation to their role in CDO management. This problem was illustrated in the US in Rabobank $v$. Merrill Lynch ${ }^{120}$, where the defendant acted as underwriter and sponsor for the issue of a hybrid CDO. Rabobank, as investor in the CDO, claimed that Merrill Lynch fraudulently misrepresented the safety of the investment and understated the level of risk attached to the plaintiff's position. In particular, Rabobank argued that the marketing material circulated by the defendant promised that the collateral manager, NIR Capital Management, was appointed because of the experience, expertise and independence it could bring in structuring the transaction and selecting a reference portfolio with "superior risk adjusted returns". The claim also stated that the collateral manager did not

\footnotetext{
${ }^{118}$ Supra Moloney 2014, p.374.

${ }^{119}$ See Clifford Chance "New Beginnings", 2009, p.5.

${ }^{120}$ Cooperative Centrale Raiffeisen-Boerleenbank BA v. Merrill Lynch \& Co No.09-601832 (NY State Supreme Court Jun 12 2009).
} 
effectively conduct any rigorous study on the assets, nor did it select the portfolio which had already been selected by Merrill Lynch. ${ }^{121}$ Like in the Abacus case, this dispute was settled and the collateral manager was not involved in the proceedings. ${ }^{122}$

More recent cases however have shown possible developments as regards asset managers' position in structured transactions. In June 2013 a New York lawsuit was filed by Northern Rock in connection with a CDO structured and marketed by Societe Generale. ${ }^{123}$ It was alleged that Societe Generale fraudulently provided misleading information concerning the quality of the CDO's collateral and the independence of the asset manager (Strategos Capital Management). Unlike similar cases, the collateral manager was involved as codefendant in the lawsuit for having cooperated in making false and deliberately misleading representations on the stability of the CDO. ${ }^{124}$ At the time of writing, the court has denied the defendants' motion to dismiss Northern Rock's fraud cause of action. ${ }^{125}$

More significantly, in October 2013, the SEC started proceedings against Harding Advisory LLC, for the role it played as collateral manager to a synthetic CDO structured and marketed by Merrill Lynch in 2006. The SEC alleged that Harding compromised its independent judgement in the selection of assets as it gave a hedge fund (Magnetar Capital LLC) rights over the selection of the CDO collateral, without disclosing Magnetar's adverse economic interest in the transaction to investors. ${ }^{126}$ The SEC stressed that Harding was aware of the hedge fund's equity position in the CDO and of its hedging strategy that would profit

\footnotetext{
${ }^{121}$ Ibid. The claim went on to suggest that the relationship between Merrill Lynch and NIR fell short of the ideal arm's length relationship suggested by the defendant and that Merrill Lynch had instead assembled a "stable of small firms to manage its CDOs that would be beholden to Merrill Lynch on account of the business it funnelled to them.

${ }^{122}$ Unrelated to this suit, NIR became subject of a SEC investigation that resulted in a lawsuit against NIR for defrauding investors and making materially false and misleading statements to investors. See SEC v. NIR Group, No.11-04723, Oct 22012.

${ }^{123}$ Northern Rock Plc v. SGCIB, Cohen \& Co Securities, Strategos Capital Management LLC, Supreme Court of the State of New York, Summons with Notice, 652033/2013.

124 Ibid.

${ }^{125}$ Northern Rock Plc v. SGCIB, Cohen \& Co Securities, Strategos Capital Management LLC, Supreme Court of the State of New York, 2014 NY Slip Op 32155(U). A similar action involving an asset manager was recently decided in the same way in CIMB Thai Bank Plc v. Morgan Stanley, 2013 NY Slip Op 32264(U).

${ }^{126}$ SEC v. Harding Advisory LLC and Wing F. Chau, Release 2013/224.
} 
from the failure of the CDO. The charges brought by the SEC revolved around Harding's misrepresentation and omission regarding the selection of assets. This triggered violations of s.17(a) Securities Act 1933 (fraudulent conduct in the offer and sale of securities) and s.206 (1 and 2) Investment Advisers Act 1940 (fraudulent conduct by an investment adviser which implies a breach of fiduciary duty). ${ }^{127}$ In 2015 the SEC confirmed the respondents' violation of the above provisions, ordering the payment of $\$ 1,003,216$ in disgorgements and civil penalties of $\$ 1.7$ million. ${ }^{128}$ The problem however remained that the parallel action brought by investors against Harding, the underwriter and the trustee (for having failed to pay under the indenture agreement) was dismissed against all but the trustee, for reasons that have been explored in the previous section, namely a no-action clause in the indenture agreement. ${ }^{129}$

\section{D - Bridging the accountability gap}

\section{1 - Fiduciary law}

The legal problems so far discussed - the lack of accountability of the parties involved in the management of complex structured products - could be mitigated if the central roles in these transactions were to be configured under a broad fiduciary rationale. The application of fiduciary law in structured finance has become a very topical discussion because it could achieve the ambitious goal of regulating the relationship between investors and investment banks and thus impose obligations directly upon the latter as ultimate advisor in the transaction. This legal construction however has proven problematic under both UK and US legal tradition. Moreover, it finds difficult application in the context of structured finance, because the relationship between investors and sponsors/originators is not contractual and the

\footnotetext{
127 Ibid.

${ }^{128}$ Initial Decision Release N.734 before the SEC in the matter of Harding Advisory LLC and Wing F. Chau, January 12 2015. Harding was also revoked the investment adviser registration and Chau was barred from association with the securities industry.

${ }^{129}$ RJ Capital, S.A. v. Lexington Capital Funding III, Ltd. et al, No. 1:2010cv00025 - Document 44 (S.D.N.Y 2011).
} 
latter's role as advisor is disclaimed. As illustrated throughout this article, the interposition of the SVP between investors and originators entails that noteholders have no direct legal relationship outside the one with the SPV. So the key question remains: can a broader fiduciary duty be constructed upon originators/sponsors for the central role they play in complex structured transactions?

In the UK and the US legal tradition, fiduciary duties of honesty and good faith arise for company directors by virtue of the delegation of managerial powers from shareholders. Directors are therefore required to refrain from self-interested behaviour. ${ }^{130}$ In this sense, a fiduciary is "someone who has undertaken to act for or on behalf of another in a particular matter in circumstances which give rise to a relationship of trust and confidence". ${ }^{131}$ Beyond this, fiduciary duties attach to commercial relationships only in a limited range of cases, typically where a commercial organisation is dependent on another that can determine its interests, or where a commercial entity seeks the advice of professionals (which would be the case of bankers, advisors, lawyers). ${ }^{132}$

Thus, in standard banker/customer relationships a fiduciary relationship would not normally arise. ${ }^{133}$ However, as modern financial transactions evolved, certain relationships that were originally conceived between counterparties dealing at arm's length, started to invoke the fiduciary role of the party acting as advisor, which entailed a trust relationship and could thus trigger equitable remedies actionable by the advised party. ${ }^{134}$ This assertion became more common in the 1990s as relationships between banks and large sophisticated organisations started to be characterised by the advice provided by the former on complex

\footnotetext{
${ }^{130}$ L. Ribstein "Fiduciary Duties of Investment Bankers: Senate Testimony", May 42010 Illinois Law and Economic Research Paper Series No.LE10-019, p.4. The configuration of directors as trustees was also envisaged in UK by Professor L. Sealy "The Director as Trustee" (1967) CLJ 83.

${ }^{131}$ Bristol and West Building Society v. Mothew [1998] Ch. 1.

${ }^{132}$ C. Bamford "Principles of International Financial Law", OUP 2011, p.207.

133 A. Hudson "The Law of Finance", Sweet \& Maxwell, 2013, p.102; Kelly v. Cooper [1993] AC 205.

134 Supra Bamford 2011, p.174,175. This relationship was invoked most prominently in Bankers Trust International Plc v. PT Dharmala Sakti Sejahtera, [1996] CLC 518.
} 
financial arrangements. The notion of fiduciary relationship in a financial context was recently conceptualised by the Federal Court of Australia with a definition that stressed the advisory role of a party that is also an expert in financial matters and undertakes to perform that role for the client. ${ }^{135}$ In Asic v. Citigroup this definition encompassed a number of situations that revolve around the need to avoid conflicts of interest as well as the confidential treatment of customers' affairs. ${ }^{136}$ These can arise in a number of situations, namely: 1) where the bank induces a transaction by agreeing to become advisor; 2) where the bank advises an inexpert customer who relies entirely on the bank's expertise; 3) where a bank has discretionary control of a customer's assets; 4) where the bank advises a party to enter into a transaction without ensuring that it has taken independent advice. ${ }^{137}$

As anticipated however, the application of fiduciary duties to financial transactions has been ostracised both in the UK and in the US. It has been argued in this sense that applying the fiduciary concept to financial dealings would bring about uncertainty as to the nature of the duties to be applied in specific circumstances, because they can range between due care, good faith, confidentiality, absence of self-dealing. ${ }^{138}$ Fiduciary duties in other words are considered an "amorphous" concept to be applied to financial transactions as a standard-setter because of the resulting vagueness of the underlying obligations, which, as said, would lead to uncertainty. ${ }^{139}$

Another strong argument in this sense is that in the context of commercial and financial dealings, parties are assumed to be able to deal at arm's length and serve their own interests through contractual relationships entered into in good faith. ${ }^{140}$ Similarly, it has been

\footnotetext{
${ }^{135}$ Australian Securities and Investment Commission v. Citigroup Global Markets Australia Pty Ltd [2007] FCA 963.

136 Ibid.

${ }^{137}$ A. Hudson "The Law of Finance", Sweet \& Maxwell 2009, p.103.

${ }^{138}$ Supra Ribstein 2010, p.6.

${ }^{139}$ Ibid, p.7.

${ }^{140}$ Ibid p.2. See also Katz v. Oak Industries Inc, 508 A2d 873 (Del. Ch. 1986), where the duty to bargain in good faith involved the duty of a company to holders of debt securities, and the issue was whether the duty was to be determined by the covenant or by the court applying a default fiduciary duty.
} 
observed in UK courts that unless one of the parties in a financial transaction is an individual retail customer, as in Lloyds Bank Ltd v. Bundy ${ }^{141}$, courts will be very reluctant to recognise fiduciary duties beyond what parties agreed in the terms of the contract. Banks in other words do not normally owe fiduciary duties to their customers unless something special about the relationship moves the bank into acting in a trustee-like capacity. More specifically, this would be the case anytime a bank has discretionary power over customers' assets and exerts undue influence (a narrower framework than the one laid out in Asic v. Citigroup). ${ }^{142}$

Despite the reluctance to recognise fiduciary protection to parties involved in financial transactions, some specific situations can be identified for the possible construction of a fiduciary relationship, regardless of the sophistication of the parties involved. The first scenario would be the sale of complex products to clients that, regardless of sophistication, have no specific expertise in the field. This would be the case of derivatives or structured products whose risk profile is based on mathematical models. Complexity and inaccessibility are said to trigger in such cases the dependency of one party on the advice of the other, which would as a consequence defeat the assumption of arm's length contracting. ${ }^{143}$ This argument however, would be more difficult to construe in securitisation-type transactions where the sale of complex products is conducted by the SPV and the bank's advisory role is more remote and difficult to configure (as it is normally excluded by contractual provisions).

A possible application of this fiduciary protection is illustrated in a number of UK cases which, it is worth bearing in mind, do not deal specifically with securitisation-type products. In Bankers Trust International Plc v. PT Dharmala Sakti Sejahtera, in the context of a swap contract entered into by the claimant, the court rejected the argument that the defendant had acted as advisor and as such had failed to warn PT Dharmala of the risks of the

\footnotetext{
${ }^{141}$ [1975] 1 QB 326. In which case courts will apply equitable remedies as a consequence of the trust and confidence placed on the advisor.

${ }^{142}$ Supra Bamford 2011, p.228.

${ }^{143}$ Ibid, p.229.
} 
transaction. ${ }^{144}$ The claim was based on the alleged breach of the defendant's duty of care, for having inter alia failed to advise. The claim eventually failed because the court was not convinced that the circumstances of the case led to a banker-customer relationship that could justify fiduciary protection. ${ }^{145}$

A similar conclusion was reached in JP Morgan Chase Bank v. Springwell Navigation Corporation $^{146}$, where the claimant entered into contracts with the bank to purchase complex debt instruments, which resulted in heavy losses related to the 1998 market collapse. The various claims, grounded on the breach of duty of care for having failed to advise appropriately, on misrepresentation of the transaction's risk, and on the existence of a fiduciary duty on the bank, were all refuted by the court. The judgment was grounded on the lack of any written agreement that could substantiate the bank's obligation to provide advice and on the lack of evidence suggesting that such position had been undertaken by JP Morgan. For these reasons, the fiduciary argument was strongly rejected by the court. ${ }^{147}$ The fact that there were no contractual elements to substantiate a fiduciary relationship highlights the ability of banks to draft contractual terms that disclaim the existence of any fiduciary relationship with the client. ${ }^{148}$

Another critical scenario where a fiduciary protection may be invoked by investors, and potentially recognised, occurs where one party in the course of a transaction does not have the necessary information to monitor the other party's behaviour and protect its own interests. This would typically be the case in transactions where one party cedes discretion to another in relation to important financial matters, for instance when bondholders appoint a trustee in a bond issue. As previously explained, bondholders rely on trustees for protecting

\footnotetext{
144 [1996] CLC 518.

145 Supra Bamford 2011, p.230.

146 [2008] EWHC 1186 (Comm).

${ }^{147}$ Ibid.

${ }^{148}$ Supra Bamford 2011, p.232. Similarly, in Titan Steel Wheels Ltd v. The Royal Bank of Scotland Plc [2010] EWHC 211 (Comm), an exclusion of duty of care was binding between the parties.
} 
their rights and eventually bringing an action in their interest. ${ }^{149}$ However, despite trusteeship being traditionally associated with fiduciary relationships, this configuration has found scarce application in the context of financial transactions because of the sophistication of the parties involved, which entails that they are deemed capable of looking after their interests, and most importantly because there is not direct trust relationship between investors and those at the heart of CDO management. ${ }^{150}$

To sum up, the use of trustees in structured transactions does not automatically entail a tout court fiduciary protection owed to investors. This is partly due to the application of contractual arrangements that exclude a fiduciary responsibility beyond the function that is specifically set out in the contract. ${ }^{151}$ A similar view on the contractual nature of bondholders' rights in structured finance is shared in the US, where it is suggested that bondholders should be owed only those duties that arise by virtue of the contract they entered into with the issuer. ${ }^{152}$ The contractual nature of debt transactions in other words excludes the applicability of fiduciary duties, which could be loosely configured only when clear contractual obligations are absent and courts recognise a contractual duty of good faith. Above and beyond this difficulty, policy reasons grounded on efficiency and economic rationale have also pointed in the same direction. The argument is that extending fiduciary protection to bondholders may affect firms' attitude towards risk-taking because of the fixed nature of bondholders' claim, which is naturally divergent from equity-holders. ${ }^{153}$

\footnotetext{
${ }^{149}$ Ibid, p. 235.

${ }^{150}$ Ibid p. 236. This argument is emphasised in the context of CDOs which are issued by SPVs in private placements to sophisticated investors. In such situations, delegation of power (to trustees) resides in convenience rather than necessity, as it is explained in Elektrim SA and another $v$. Law Debenture Trust Corporation PlC and another [2008] EWCA Civ 1178 where it was observed that the use of a trustee was a way of centralising administration and enforcement of bonds, and does not entail or justify the application of a fiduciary protection to bondholders.

${ }^{151}$ See on this: Titan Steel Wheels Ltd v. The Royal Bank of Scotland Plc [2010] EWHC 211 (Comm); JP Morgan Chase Bank v. Springwell Navigation Corporation [2008] EWHC 1186 (Comm).

152 R.D. Ellis "Securitization Vehicles, Fiduciary Duties, and Bondholders' Rights", 24 The Journal of Corporation Law 296, 1998-99, p.311.

${ }^{153}$ Supra Ellis 1999, p.315.
} 
On a final note, while fiduciary protection to bond investors seems to have very limited application for the reasons above illustrated, it needs to be observed that statutory provisions enacted in the UK, US and at EU level have established regimes that aim to protect the interests of investors in financial transactions in a fiduciary-type way. This was the case of the FSMA 2000 that introduced inter alia principles of integrity, customer interests, conflicts of interest, relationship of trust ${ }^{154}$, and more recently of MiFID and MiFID II of which mention has been made earlier in the article. As already pointed out however, much of this regulatory framework is directed at protecting retail investors, whereas the more specific context of wholesale structured transactions has remained only loosely regulated.

\section{2 - The law of misrepresentation}

Investors in CDOs are likely to be professional or sophisticated, and as a consequence will not be afforded the same degree of protection that is available to retail investors under MiFID and MiFID II classifications. As explained, parties' liability will largely be determined by the contractual agreements they entered into. The potential to establish some degree of accountability for the management and control of CDOs' assets may then lie on claims of misrepresentation.

A fundamental question that emerged in a number of recent disputes ${ }^{155}$ is whether claims for misrepresentation as to the credit quality could be successfully brought by CDO investors. The recurring argument is that they are induced to invest by the arranging/sponsoring bank that makes express statements as to the creditworthiness, quality and performance of the assets in the CDO portfolio. ${ }^{156}$ In essence, while the ultimate sale of the notes is conducted by the SPV, the marketing material related to the CDO is provided by

\footnotetext{
${ }^{154}$ FSMA 2000, ch.8, part 5.

${ }^{155}$ See V. Bavoso "HSH v UBS: Lessons from New York", Journal of International Banking and Financial Law Vol.28 No.6, 2013.

${ }^{156}$ S. Clarke, E. Lamberton "Collateral Damage: A Reference Pool of CDO Claims", Journal of International Banking Law and Regulation, 2010, 25(7) 315, p.316.
} 
the investment bank acting as sponsor. This is important as it delineates the type of action that can be brought by investors, namely a fraudulent misrepresentation (deceit) where investors would face the difficulty of proving the fraud ${ }^{157}$; a statutory claim under s.2(1) of the Misrepresentation Act 1967, which presupposes the existence of a contractual relationship between representor and representee ${ }^{158}$; and a common law claim for negligent misrepresentation where the scope of liability in tort can be widened, following Hedley Byrne v. Heller ${ }^{159}$, to include a misrepresentation made by a third party (the originator/sponsor), provided the existence of a special relationship between claimant and defendant and reliance of the former on the misstatement.

The argument normally brought by investors is that the sponsoring bank is aware that the representations made on the product's credit quality are false and this is often corroborated by the bank's privileged position as regards structuring and trading complex products. ${ }^{160}$ This results allegedly in an "apparent product risk" that is disclosed to investors via credit rating agencies, and in a "real risk" that is known only by the sponsor. ${ }^{161}$ The problem of ascertaining the level of risk in structured products is a consequence of their complexity and of the inherent information asymmetry that persists between investors and sponsors.

Clarifications on this type of claim were recently provided in the New York case between HSH Nordbank AG v. UBS AG where actions for fraud and negligent misrepresentation were brought in relation to the stability of the CDO and the manner in which UBS managed the underlying assets. UBS was alleged inter alia to have induced HSH

\footnotetext{
${ }^{157}$ According to the framework established in the UK with Derry v. Peek (1889) 14 App Cas 337 whereby the representee has to prove that the representation was made knowingly, without belief in its truth or recklessly.

${ }^{158}$ Outside cases like Cassa di Risparmio della Repubblica di San Marino SpA v. Barclays Bank Plc, [2011] EWHC 484 (Comm), where CDOs were sold directly by Barclays, securitisation-type transactions include the interposition of the SPV as issuer of the notes, which would exclude the application of s.2.

159 [1964] AC 465.

${ }^{160}$ In this sense, Employees Retirement System of the Government of the Virgin Islands v. Morgan Stanley \& Co, US District Court SDNY, No.09-10532, 2011.

${ }^{161}$ Supra Clarke and Lamberton 2010, p.317. See also Cassa di Risparmio della Repubblica di San Marino SpA v. Barclays Bank Plc, [2011] EWHC 484 (Comm), where this argument was proposed.
} 
to invest in a product they would not have purchased had they been aware of the true risk attached to it. ${ }^{162}$ The Supreme Court dismissed HSH's claims on a number of grounds. Firstly, it stated that because of the detailed disclosure and disclaimers it was unjustifiable for $\mathrm{HSH}$ to rely on UBS' representations concerning their intended trading strategy and economic interest in the deal; this entailed that any limitation on UBS' discretion in managing the reference pool should have been incorporated in the transaction's documents. ${ }^{163}$ Secondly, it clarified that the facts allegedly misrepresented by UBS could have been learned by HSH through an independent appraisal of the transaction's risks, a duty that also took into account the appellant's sophistication. ${ }^{164}$ Thirdly, this line of argument also considered HSH's disclaimer of reliance on UBS for advice on extra-contractual representations and the specific disclosure of risk and conflict of interest in the transaction documents. ${ }^{165}$ Fourthly, the Supreme Court pointed to the express agreement whereby the parties were dealing at arm's length, which implied that UBS was not acting as HSH's investment advisor and HSH was not relying on advice or representations from UBS. ${ }^{166}$

The central question of whether advice is provided or not in the sale of complex structured products was clarified in the Cassa di Risparmio case, where the claimant argued that product complexity implied that investors would need details on the risks of the reference assets in order to reach informed decisions on the investment. ${ }^{167}$ Courts however have addressed this issue by simply looking at parties' roles in the transactions, which are determined by the contractual arrangements entered into and by the way they agreed to share risks and liabilities. ${ }^{168}$ This was further illustrated in the Springwell case, where the absence

\footnotetext{
${ }^{162}$ Complaint filed in the Supreme Court of the State of New York, 2008.

${ }^{163}$ HSH Nordbank AG v UBS AG, 2012 NY Slip Op 02276.

164 Ibid.

165 Ibid.

166 Ibid.

${ }^{167}$ Cassa di Risparmio della Repubblica di San Marino SpA v. Barclays Bank Plc [2011] EWHC 484 (Comm).

168 Ibid. The court pointed to "non-reliance" clauses found in the transaction documents, where Cassa di Risparmio agreed that it was not relying on any communication from Barclays as investment advice or as a recommendation to enter into the transactions.
} 
of a written agreement led the court to exclude the existence of an advisory relationship ${ }^{169}$, and in Titan Steel, where the contract established that no advisory services - but mere opinions - were provided by RBS. ${ }^{170}$ Again, the three above cases were not securitisationtype transactions but sales of structured product conducted directly by investment banks.

An unusual approach emerged in the more recent US case ACA Financial Guaranty Corp. v. Goldman Sachs \& Co. ${ }^{171}$ where the plaintiff alleged to have been induced into insuring a CDO by Goldman Sachs' fraudulent misrepresentation of a hedge fund's adverse economic interest in the transaction. ACA's allegations revolved around the role of a hedge fund (Paulson) in the selection of the CDO's collateral and in its economic interest. Goldman Sachs misrepresented to ACA that Paulson had taken a long position in the CDO, whereas Goldman Sachs had secretly entered into a separate CDS with Paulson that gave the hedge fund protection over the reference portfolio (resulting in a short position). The court found that the fraudulent misrepresentation was not deemed discoverable by ACA through any publicly available information, and therefore ACA had justifiably relied on Goldman Sachs' misrepresentation, regardless of its sophistication. ${ }^{172}$ The above ruling was reversed in appeal where the court took a different approach to ACA's complaint. ${ }^{173}$ It observed that ACA's reliance on the alleged misrepresentation was contrary to the acknowledgment that ACA was not relying on any advice and that Goldman was not acting as its fiduciary. The court also stated that ACA could have uncovered the hedge fund's short position by questioning directly

\footnotetext{
169 [2008] EWHC 1186 (Comm).

170 [2010] EWHC 211 (Comm).

1712012 NY Slip Op 50723(U). This case was connected with the 2007 Abacus CDO discussed earlier.

${ }^{172}$ In this sense also NRAM PLC v. Societe Generale Corporate and Investment Banking et al., case number 652033/2013, in the Supreme Court of the State of New York, where the court accepted Northern Rock's argument that the defendant possessed peculiar information on the quality of the collateral and that it had misled rating agencies on the value of the CDO's collateral. The court further stressed that no amount of due diligence on the part of Northern Rock could have discovered the misrepresentations and concealments.

${ }^{173}$ ACA Financial Guaranty Corp. v. Goldman Sachs \& Co., case number 650027/2011, in the Appellate Division of the Supreme Court of the State of New York, First Judicial Department.
} 
the defendant and the hedge fund, but instead chose not to. ${ }^{174}$ In essence, the court found that ACA had failed to establish justifiable reliance on Goldman's misrepresentation. ${ }^{175}$ In 2015 the Court of Appeal reinstated the fraud action against Goldman Sachs and the 2013 Appellate decision was reversed on grounds that ACA sufficiently pleaded justifiable reliance and that the defendant failed to submit evidence that established conclusive lack of justifiable reliance. ${ }^{176}$

Despite the approach in ACA (where it is worth remembering, the plaintiff was not an investor but the CDO manager), courts in both the US and the UK remain concerned with upholding the terms of the contract entered into by the parties (deemed sophisticated). The policy priority in other words is to allow that "two businessmen agree that the buyer is not buying in reliance on any representation of the seller". ${ }^{177}$ This essentially entails that without the possibility of establishing reliance, it would be very difficult for UK investors to substantiate the special relationship that is presupposed under a common law claim. ${ }^{178}$ Equally, for US investors the claim would be complicated by the mechanics of Rule 10-b5 ${ }^{179}$, where plaintiffs have to show two forms of causation, namely transaction causation and loss causation, whereby the former implies reliance. ${ }^{180}$

\section{E - Critical reflections and conclusion}

The analysis conducted in this article highlights the central role played by investment banks as sponsors of complex structured transactions. This centrality has a twofold significance. Firstly, investment banks enjoy an intrinsic asymmetry of information because they engineer

\footnotetext{
${ }^{174}$ Ibid. On this critical point the court remained divided with two judges out of five maintaining that Goldman Sachs concealed information that was not publicly available and therefore ACA fulfilled its due diligence responsibility.

175 Ibid.

${ }^{176}$ ACA Fin. Guar. Corp. v Goldman, Sachs \& Co. 2015 NY Slip Op 03876, May 7, 2015 Court of Appeals.

177 Supra HSH v. UBS 2012 p.11.

${ }^{178}$ Hedley Byrne v. Heller [1964] AC 465.

17917 C.F.R. 240.10b-5.

${ }^{180}$ See Dura Pharm., Inc. v. Broudo, No. 03-932, 2005 WL 885109 (Apr. 19, 2005), and more specifically on transaction causation Basic Inc. v. Levinson, 485 U.S. 224, 248-49 (1988).
} 
and structure the complex financial products that are subsequently marketed to investors. This has allowed them to maintain a marginally better understanding of the risks attached to complex securities and the quality of the underlying collateral. As it is explained in this article, information asymmetry becomes crucial when complex products are marketed and sold to investors. Secondly, investment banks have retained a privileged position in the negotiation of transaction documents which effectively determine the duties of the parties involved in the management of CDOs and their eventual liabilities. This contractual imbalance leaves an accountability gap due to the difficulty of establishing liability against SPV directors, trustees and asset managers.

The recent litigations related to CDO claims have not contributed to clarify the legal problems identified in this paper, namely: the extent of applicable duties, the nature of conflicts of interest, and the misrepresentation of transactions' risk. This is so largely because courts have reiterated that despite complexity and information asymmetry, a sophisticated organisation should be able to discover the essence of the transaction through publicly available information and protect its own interests. This assumption is however inconsistent with the very essence of synthetic CDOs, because the opaqueness of these legal relationships conceals risks and conflicts of interests often impossible to unveil. ${ }^{181}$ Moreover, parties deemed sophisticated are often not entirely proficient with the mechanics of debt capital markets (the case of commercial banks for instance) and this widens their information gap vis-à-vis investment banks.

This article also reflected on the evolution of structured finance, which has largely remained unbridled because regulation in this area was thought to stifle innovation in financial markets. ${ }^{182}$ The regulation of these transactional models has therefore remained fragmented and it has failed to comprehensively address issues of parties' liability and

\footnotetext{
${ }^{181}$ This is reflected in the modus operandi that characterised some of the cases analysed in the article, namely SEC v. Goldman Sachs and SEC v. Harding.

${ }^{182}$ Supra Schwarcz 2012.
} 
product risk (MiFID II exemplifies this problem as it fails to regulate more specific conflicts of interest arising in contexts of underwriting and asset management ${ }^{183}$ ).

In the wake of the GFC a broader configuration of fiduciary law could be advocated as a way to bridge originators/sponsors' accountability to investors. This solution however would be of difficult implementation due to the traditional judicial orientation in the UK and US and also because the extent of the fiduciary obligation in finance remains vague and too broad. $^{184}$

This article contends that a more comprehensive approach to the regulation of complex structured transactions is needed. The problem, as outlined in the introduction, has emerged recently in the context of the proposal to revive the EU securitisation market and to define "high-quality securitisation". While the initiative was commendable, it failed to adequately address questions of transaction standardisation. ${ }^{185}$ This is relevant to the present discussion because the conclusions provided in parts C and D of this article suggest that the primacy of contract that govern these transactions results in clear limits to the accountability that parties in the management of CDOs have against investors. It was explained earlier that this is partly due to the complex chain of legal relationships in CDOs, but it is equally evident that contractual imbalances allow the parties in a privileged bargain position to impose limitation of their liability. The sanctity of contract in other words leads to the suboptimal governance of structured transactions because it does not account for parties' different bargain power and asymmetry of information. In turn this has resulted in the widening of the accountability gap.

This article suggests that the chain of contractual relationships in complex securitisation-type transactions should be defined and standardised by statute. Despite being

\footnotetext{
${ }^{183}$ Supra Moloney 2014, p.372.

${ }^{184}$ L. Ribstein "Fiduciary Duties of Investment Bankers: Senate Testimony", May 42010 Illinois Law and Economic Research Paper Series No.LE10-019, p.7.

${ }^{185}$ For a discussion, see V. Bavoso "High Quality Securitisation and Capital Markets Union - Is it Possible?", Convivium, forthcoming 2016.
} 
inconsistent with much of the Anglo-American legal tradition in this area of law, this would achieve a twofold purpose. Firstly, it would define (and crystallise) the scope of transactions and products, providing therefore an element of clarity to investors and the market as a whole; and secondly, it would provide ad-hoc regulation of specific components of these complex relationships. In particular, statute-based regulation could define the roles of the parties involved in the management of CDOs, and set specific duties which would provide much needed accountability (for instance an automatic advisory role of originators/sponsors). This design would result in a transaction-based regulation that would codify a set of tailor-made duties which, despite being fiduciary in nature, would find automatic application and provide certainty and accountability in these complex legal relationships. 


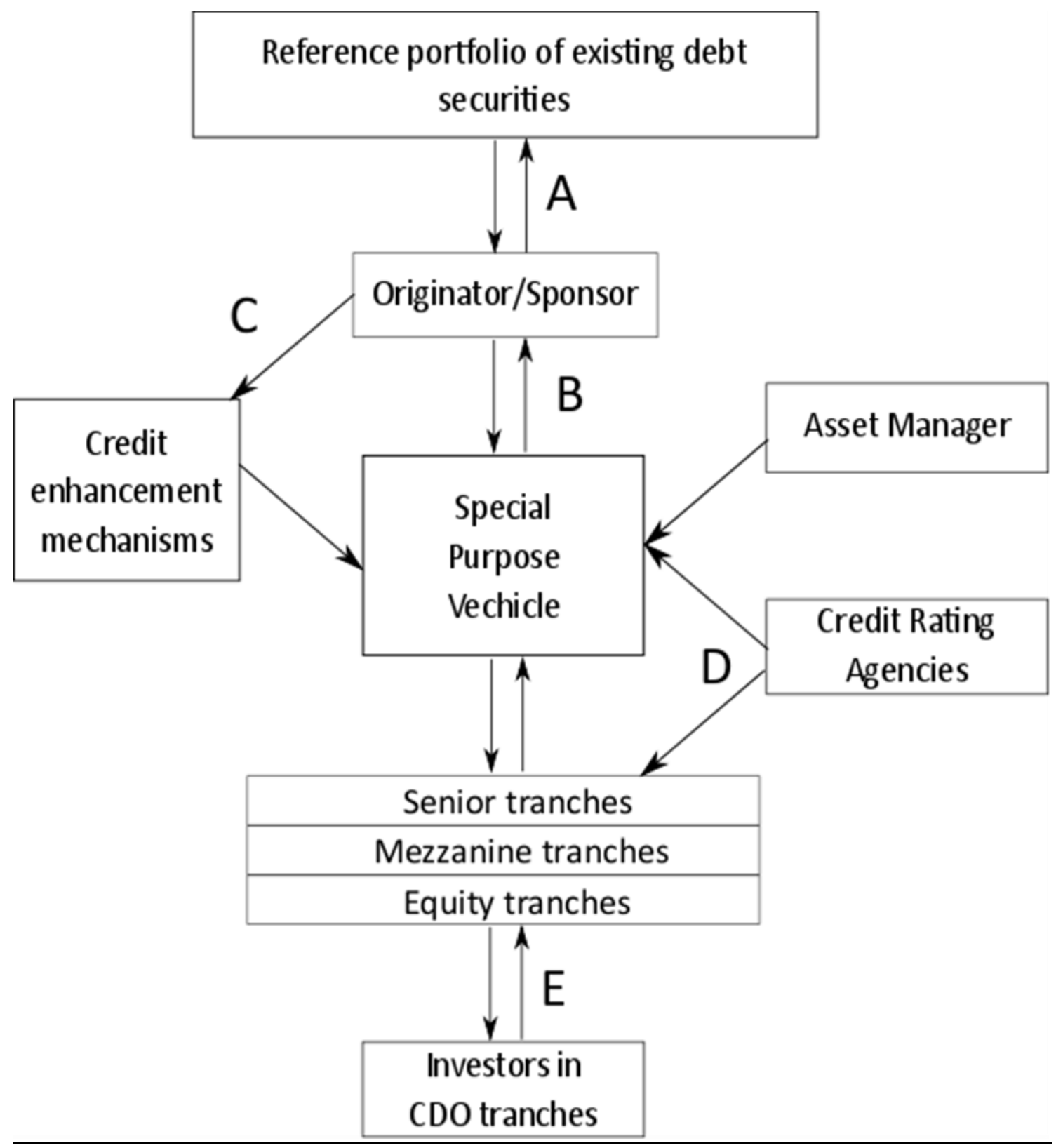

A-The originator/sponsor selects together with an asset manager a portfolio of existing debt securities;

B-The securities are sold (true sale) to a SPV that will issue CDOs to investors secured over the reference assets;

C-Credit enhancement mechanisms (sponsor's guarantees or monoline insurance) ensure the SPV's rating;

D-Credit rating agencies advise on the structure of the CDO; they then rate the different tranches;

E-Investors purchase tranched notes in the CDO according to their preferred level of risk and return; 


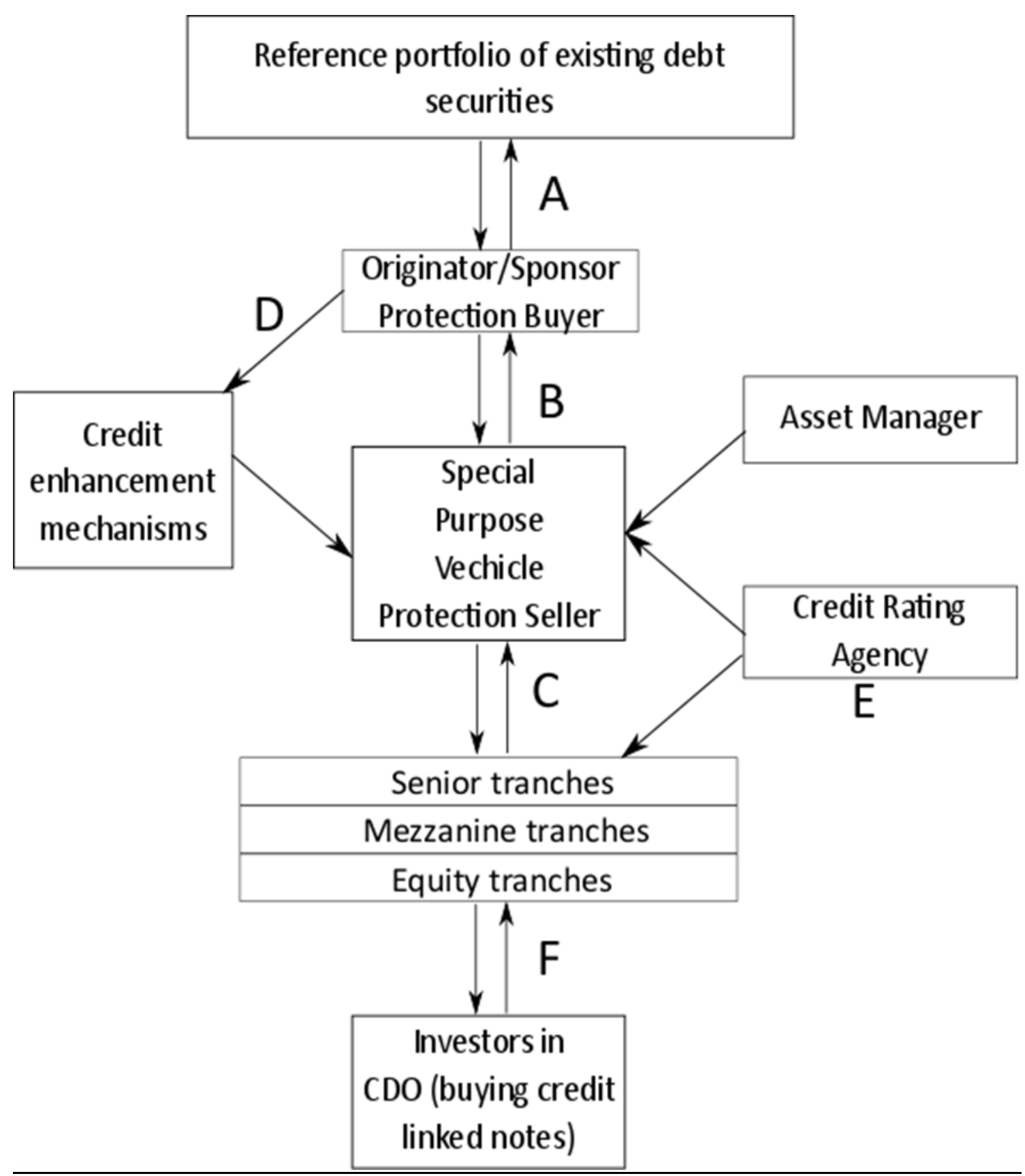

A-The originator/sponsor selects together with an asset manager a reference portfolio of existing debt securities;

B-The originator/sponsor enters into a Credit Default Swap with the SPV to transfer risks related to the reference portfolio;

C-The SPV creates securities (CDO tranches) whose cash-flow derives from the CDS contracts - where the SPV acts as protection seller - instead of the asset pool;

D-Credit enhancement mechanisms (sponsor's guarantees or monoline insurance) ensure the SPV's rating;

E-Credit rating agencies advise on the structure of the CDO; they then rate the different tranches;

F-The SPV issues Credit Linked Notes (CLN) to investors, thereby passing to them the credit risk related to the specific CDO tranche they purchase; 
Diagram 3 - Illustration of Abacus-type synthetic transaction

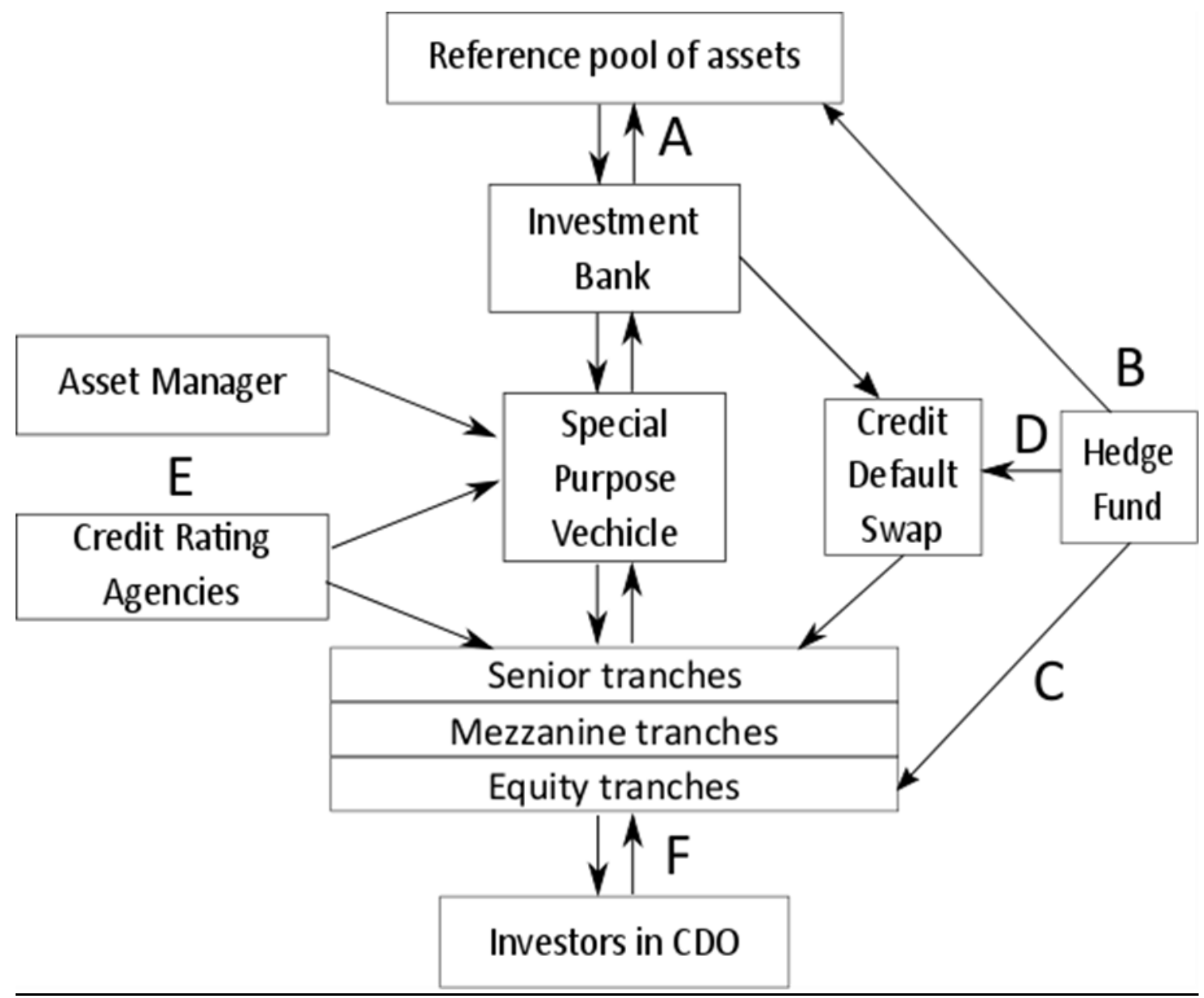

A-Goldman Sachs, together with asset manager ACA and hedge fund Paulson, select a portfolio of debt securities (RMBS) in order to structure a synthetic CDO;

B-The hedge fund's role in selecting assets was atypical; investors relied on ACA's role in the certification of the selection process;

C-The hedge fund invested in the equity tranche of the CDO to gain investors' confidence in the structure;

D-The hedge fund then secretly entered into a CDS with Goldman Sachs to short the CDO's senior tranches;

E-The asset manager and the credit rating agencies were allegedly not aware of Paulson's adverse economic interest in the transaction;

F-Investors purchased senior tranches in the CDO, presumed to be low-yielding and safer, not knowing that the assets had been selected by Paulson who knew they would default and bet against them; 


\section{Diagram 4 - Example of CDO management}

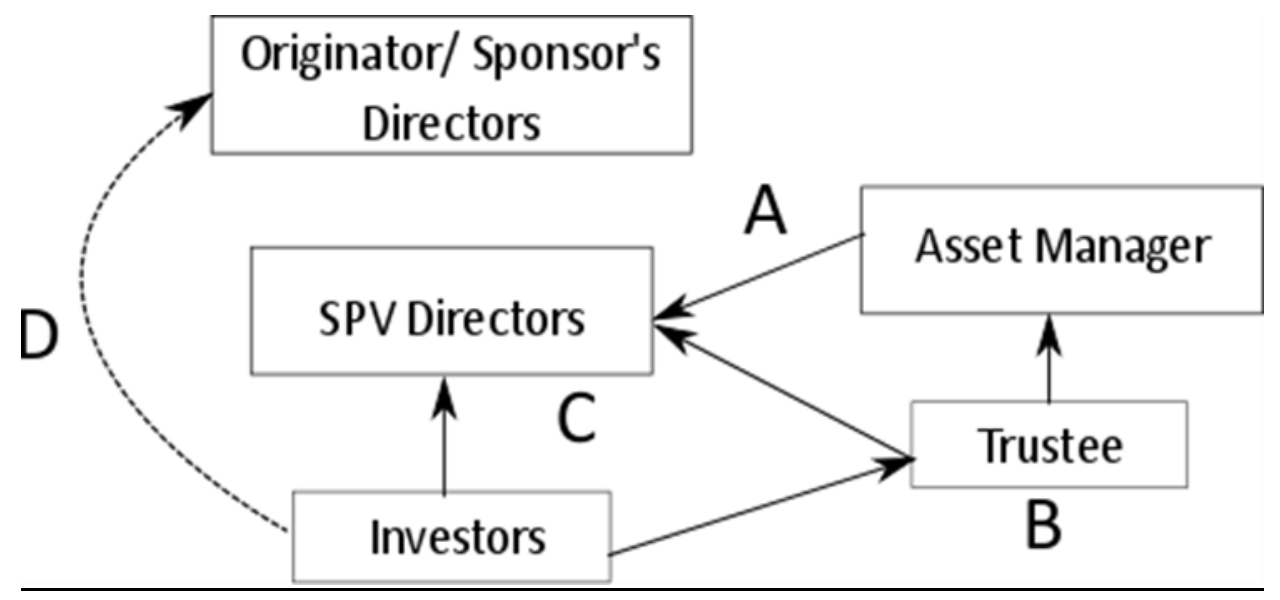

A-Asset managers are nominated by the originator/sponsor and have a contractual relationship (Portfolio or Collateral Management Agreement) with the SPV, for which they manage the assets and participate in their selection;

B-Trustees' powers are chiefly triggered in post-default scenarios; they have a fiduciary duty to noteholders but their liability is effectively determined by transaction documents;

C-SPV directors have limited and residual powers; most of the decisions related to the asset portfolio held by the SPV are taken by asset managers and by trustees in post-default scenarios;

D-Investors' option to hold the originator to account rely on difficult actions for misrepresentation or breach of fiduciary duties; 